Revista lus et Praxis, Año 22, № 1, 2016, pp. 187 - 226

ISSN 0717 - 2877

Universidad de Talca - Facultad de Ciencias Jurídicas y Sociales

Naturaleza y alcance del asilo en el sistema interamericano de Derechos Humanos

Fernando Arlettaz

Trabajo recibido el 10 de mayo y aprobado el 7 de septiembre de 2015

\title{
Naturaleza y alcance del asilo en el sistema interamericano de Derechos Humanos*
}

\author{
NATURE AND SCOPE OF ASYLUM IN THE INTER-AMERICAN \\ SYSTEM OF HUMAN RIGHTS
}

\section{FERNANDO ARLETTAZ ${ }^{* *}$}

\begin{abstract}
RESUMEN
La cuestión del concepto, naturaleza y alcance del instituto del asilo es una de las más controvertidas del Derecho Internacional. El artículo se propone determinar el sentido y alcance actuales del asilo a partir de los instrumentos del Derecho Interamericano de los Derechos Humanos. Para eso, se apoya en los dos recientes pronunciamientos de la Corte Interamericana sobre el tema (la sentencia Pacheco Tineo y la Opinión Consultiva sobre la niñez migrante), así como en los pronunciamientos de la Comisión Interamericana. Sin embargo, una adecuada comprensión de la figura del asilo en el sistema interamericano exige su contraposición con la regulación que tiene esta figura en el sistema universal y en la denominada tradición latinoamericana de asilo.
\end{abstract}

ABSTRACT

The concept, nature and scope of asylum are among the most controversial issues in International Law. This article tries to determine the meaning and scope of asylum through the instruments of the Inter-American Law of Human Rights. For this, it stands on the two recent decisions of the Inter-American Court of Human Rights (the judgement on the Pacheco Tineo case and the Advisory Opinion on minor migrants), as well as on the decisions of the Inter-American Commission of Human Rights. An adequate comprehension of asylum in the Inter-American system also requires a comparison with the regulation of the institute in the universal system of Human Rights and in the so called Latin-American tradition of asylum.

Palabras CLAVE

Asilo, Refugio, Sistema interamericano de Derechos Humanos

KEYWORDS

Asylum, Refuge, Inter-American system of human rights

\footnotetext{
* Este trabajo se encuadra en el proyecto de investigación "Derecho de asilo en la jurisprudencia interamericana", UNISANGIL.

** Miembro del Laboratorio de Sociología Jurídica de la Universidad de Zaragoza (España). Correo electrónico: fernandoarlettaz@yahoo.com.ar.
} 


\section{Introducción}

La cuestión del concepto, naturaleza y alcance del instituto del asilo es una de las más controvertidas del Derecho Internacional. Además de las disputas de fondo que existen al respecto, el uso de terminología variada y no siempre coincidente en las distintas fuentes normativas torna el tema especialmente complejo. Esta situación, predicable del Derecho Internacional en general, es particularmente cierta en el caso del Derecho Internacional Americano (en particular, pero no únicamente, del Derecho Interamericano de los Derechos Humanos).

Este artículo se propone determinar el sentido y el alcance del asilo en los instrumentos del Derecho Interamericano de los Derechos Humanos. Aunque los debates en el campo tienen ya varias décadas de trayectoria, la temática sigue siendo de interés, como lo demuestra el hecho de que la Corte Interamericana de Derechos Humanos se ha pronunciado al respecto en 2013 y en 2014. Por otra parte, una correcta comprensión del Derecho Interamericano de los Derechos Humanos en este punto exige una referencia a las normas del Derecho Internacional de los Refugiados así como a aquellas que conforman la llamada tradición latinoamericana de asilo (y que forman parte del Derecho Internacional americano aunque no del Derecho Interamericano de los Derechos Humanos).

Hasta fecha reciente la Corte Interamericana no había abordado la cuestión del asilo, aunque en un voto particular había habido una referencia incidental al tema ${ }^{1}$. En el año 2013 la Corte dictó sentencia en el caso Familia Pacheco Tineo. En esta sentencia se abordó por primera vez de forma directa el instituto del asilo² . Al año siguiente la Corte dictó su Opinión Consultiva sobre los Derechos y garantías de niñas y niños en el contexto de la migración y/o en necesidad de protección internacional, en la que profundizó en las características de la institución en relación con los menores ${ }^{3}$.

En este trabajo proponemos el estudio del instituto del asilo en el contexto interamericano en tres pasos. En primer lugar, presentamos un abordaje conceptual del instituto, a partir de un esbozo de comprensión histórica (apartado 2). En segundo lugar, tratamos de la naturaleza del derecho de asilo (apartado 3). Finalmente, estudiamos el alcance del derecho de asilo (apartado 4) temática que, como veremos, guarda estrecha relación con la de su definición.

\footnotetext{
${ }^{1}$ Corte Interamericana de Derechos Humanos (Corte IDH): Condición jurídica y derechos de los migrantes indocumentados, voto concurrente del juez Cançado Trindade, párr. 38.

${ }^{2}$ Corte IDH: Familia Pacheco Tineo vs. Bolivia.

${ }^{3}$ Corte IDH: Derechos y garantías de niñas y niños en el contexto de la migración y/o en necesidad de protección internacional.
} 


\section{La figura del asilo}

\subsection{Aspectos históricos}

No resulta tarea sencilla dar una definición de asilo, ni distinguirlo de otras instituciones próximas. En una primera aproximación, puede decirse que el asilo es la protección que un Estado ofrece a personas que no son nacionales suyos y cuya vida o libertad están en peligro por actos, amenazas y persecuciones de las autoridades de otro Estado o por personas o grupos de personas que hayan escapado al control de esas autoridades ${ }^{4}$. O puede definirse, más sintéticamente, como la protección que un Estado otorga en su territorio o en otro lugar bajo el control de alguno de sus órganos, a una persona que llega a buscarlo ${ }^{5}$. Estas definiciones genéricas de asilo pueden aplicarse a los diversos sistemas de protección internacional a los que haremos mención, ya sea que utilicen las palabras asilo/asilado, ya sea que las reemplacen por el binomio refugio / refugiado. En el Derecho Internacional clásico, el otorgamiento de protección a un extranjero era considerado una facultad absolutamente discrecional por parte del Estado otorgante. El Derecho Internacional contemporáneo, como veremos, ha cambiado bastante esta consideración.

El origen de la figura se encuentra posiblemente en la institución medieval del asilo religioso, que permitía dar protección en lugares sagrados a los perseguidos por delitos comunes. Con la secularización de la institución se produjo también un cambio de contenido: los beneficiarios de la protección no fueron ya los perseguidos por delitos comunes, sino por delitos o motivos políticos.

La institución secular del asilo asumió dos formas: la territorial y la diplomática. El asilo territorial es concedido en el territorio del Estado que lo presta; el diplomático, en las legaciones diplomáticas. La figura se desarrolló primeramente en Europa en su forma de asilo territorial; y en algunos países, como España, también en su forma de asilo diplomático. Sin embargo, a partir del siglo XIX se produjo en Europa un rechazo a la institución del asilo diplomático. En sentido contrario, se reforzó la institución del asilo territorial y se impuso la idea de que no es procedente la extradición por delitos políticos.

Un desarrollo paralelo, aunque con matices, se esbozó en América Latina. El tratado de Derecho Internacional Penal de Montevideo de 1889 dispuso que no procede la extradición de los perseguidos políticos y que el asilo es inviolable ${ }^{6}$.

\footnotetext{
${ }^{4}$ Díez de Velasco (1985), p. 465.

5 Institut de Droit International (1950), artículo 1.

${ }^{6}$ Adoptado en Montevideo (Uruguay) el 23 de enero de 1889. Son parte: Argentina, Chile, Ecuador, Uruguay, Perú y Venezuela.
} 
Sin embargo, a diferencia de lo que sucedió en Europa, en América se afianzó el asilo tanto en su forma territorial como diplomática.

El Tratado sobre Asilo y Refugio Políticos de Montevideo de 1939 (que tuvo, por otro lado, sólo tres ratificaciones) ${ }^{7}$ estableció una distinción que, quizá, está en la raíz de buena parte de la confusión conceptual que reina en este campo $^{8}$. En efecto, el tratado usó la expresión asilo para referirse al asilo diplomático (denominado a veces también político), mientras que se refirió al asilo territorial como refugio. En una línea parecida se había ubicado la Convención sobre Asilo adoptada en La Habana en 1928 (modificada por la Convención de Montevideo de 1933) que, bajo este nombre, sólo regulaba el asilo diplomático (aunque la de 1933, que se refiere al mismo tema, se denomina Convención sobre Asilo Político $)^{9}$.

En 1954 se adoptaron en Caracas dos convenciones que se refieren, respectivamente, al asilo territorial y al asilo diplomático. La Convención de Caracas de 1954 sobre Asilo Territorial nombra a las personas protegidas como asilados o refugiados, sin establecer distinción entre estos dos vocablos ${ }^{10}$. La Convención de Caracas de 1954 sobre Asilo Diplomático, en cambio, sólo utiliza la expresión asilado para referirse a la persona beneficiada con la protección ${ }^{11}$. Sin embargo, aunque las dos convenciones usaron el vocablo asilo para indicar las dos conocidas modalidades de protección internacional, la discusión académica y política en relación con la oposición conceptual asilo/refugio no quedó totalmente cerrada ${ }^{12}$.

La Convención de Caracas sobre Asilo Territorial de 1954 consagra la facultad de los Estados de dar asilo, en sus artículos I y II. El artículo I dispone: "Todo Estado tiene derecho, en ejercicio de su soberanía, a admitir dentro de

\footnotetext{
7 Adoptado en Montevideo (Uruguay) el 4 de agosto de 1939. Son parte: Argentina, Paraguay y Uruguay.

${ }^{8}$ ESPONDA (2004), p. 98.

${ }_{9}^{9}$ Convención sobre Asilo adoptada en La Habana (Cuba) el 20 de febrero de 1928. Son parte: Brasil, Colombia, Costa Rica, Cuba, Ecuador, El Salvador, Guatemala, Haití, Honduras, México, Nicaragua, Panamá, Paraguay, Perú, República Dominicana y Uruguay. Convención sobre Asilo Político adoptada en Montevideo (Uruguay) el 26 de diciembre de 1933. Son parte: Brasil, Chile, Colombia, Costa Rica, Cuba, Ecuador, El Salvador, Guatemala, Haití, Honduras, México, Nicaragua, Panamá, Paraguay, Perú y República Dominicana.

${ }_{10}$ Adoptada en Caracas (Venezuela) el 28 de marzo de 1954. Son parte: Argentina, Brasil, Costa Rica, Ecuador, El Salvador, Guatemala, Haití, México, Nicaragua, Panamá, Paraguay, Perú, República Dominicana, Uruguay y Venezuela.

11 Adoptada en Caracas (Venezuela) el 28 de marzo de 1954. Son parte: Brasil, Colombia, Costa Rica, Ecuador, El Salvador, Guatemala, Haití, Honduras, México, Nicaragua, Panamá, Paraguay, República Dominicana y Uruguay.

12 Esponda (2004), p. 99.
} 
su territorio a las personas que juzgue conveniente, sin que por el ejercicio de este derecho ningún otro Estado pueda hacer reclamo alguno". El artículo II, por su parte, establece: "El respeto que según el Derecho Internacional se debe a la jurisdicción de cada Estado sobre los habitantes de su territorio se debe igualmente, sin ninguna restricción, a la que tiene sobre las personas que ingresan con procedencia de un Estado en donde sean perseguidas por sus creencias, opiniones o filiación política o por actos que puedan ser considerados como delitos políticos. Cualquier violación de soberanía consistente en actos de un gobierno o de sus agentes contra la vida o la seguridad de una persona, ejecutados en el territorio de otro Estado, no puede considerarse atenuada por el hecho de que la persecución haya empezado fuera de sus fronteras u obedezca a móviles políticos o a razones de Estado". Y el artículo III establece una consecuencia de los principios antes enunciados: "Ningún Estado está obligado a entregar a otro Estado o a expulsar de su territorio a personas perseguidas por motivos o delitos políticos".

La Convención de Caracas sobre Asilo Diplomático de 1954 establece principios semejantes en sus artículos I y II. El artículo I dispone: "El asilo otorgado en legaciones, navíos de guerra y campamentos o aeronaves militares, a personas perseguidas por motivos o delitos políticos, será respetado por el Estado territorial de acuerdo con las disposiciones de la presente Convención. Para los fines de esta Convención, legación es toda sede de misión diplomática ordinaria, la residencia de los jefes de misión y los locales habilitados por ellos para habitación de los asilados cuando el número de éstos exceda de la capacidad normal de los edificios. Los navíos de guerra o aeronaves militares que estuviesen provisionalmente en astilleros, arsenales o talleres para su reparación, no pueden constituir recinto de asilo". Y el artículo II agrega: "Todo Estado tiene derecho de conceder asilo; pero no está obligado a otorgarlo ni a declarar por qué lo niega".

Todos estos tratados, junto con otros de Derecho Penal o de Extradición que declaran la improcedencia de esta última en relación con delitos políticos o delitos comunes conexos, constituyen la denominada tradición latinoamericana de asilo. Las normas aplicables a cada Estado no son fáciles de determinar ya que, además de que no todos los Estados latinoamericanos son parte en todos los tratados, no se ha declarado expresamente que el instrumento posterior prima sobre el anterior y todos los tratados, a menos que dispongan otra cosa, siguen vigentes entre las partes ${ }^{13}$.

13 Galindo (2002a), p. 39. 
El Derecho Interamericano de los Derechos Humanos, por su parte, también incorporó la protección internacional de las personas perseguidas. Tanto la Declaración Americana de Derechos y Deberes del Hombre suscrita en Bogotá en $1948^{14}$ como la Convención Americana sobre Derechos Humanos de San José de $1968^{15}$ incluyeron la figura del asilo. En ambos casos, el asilo contemplado es sólo el asilo territorial.

La Declaración Americana de Derechos y Deberes del Hombre reconoce el derecho de asilo en su artículo XXVII que establece: "Toda persona tiene el derecho de buscar y recibir asilo en territorio extranjero, en caso de persecución que no sea motivada por delitos de derecho común y de acuerdo con la legislación de cada país y con los convenios internacionales".

La Convención Americana sobre Derechos Humanos reconoce el derecho de asilo en el artículo 22.7. Este artículo reproduce la norma equivalente de la Declaración Americana, aunque con una variación en relación con los motivos de la persecución. Según esta disposición: "Toda persona tiene el derecho de buscar y recibir asilo en territorio extranjero en caso de persecución por delitos políticos o comunes conexos con los políticos y de acuerdo con la legislación de cada Estado y los convenios internacionales".

Hay que tener en cuenta que desde fines de la década de 1950 (es decir, en el período comprendido entre la Declaración y la Convención Americanas) el panorama de las personas que buscaban protección internacional en América comenzó a cambiar. El enfoque tradicional circunscribía el asilo a un problema de élites políticas e intelectuales. La Revolución cubana a fines de los cincuenta, las dictaduras del Cono Sur en los años setenta y las guerras civiles centroamericanas en los ochenta mostraron la masificación del fenómeno de los solicitantes de protección ${ }^{16}$. Este hecho social tuvo una repercusión jurídica de primer orden.

El desarrollo del sistema universal de protección de los Derechos Humanos también afectó la cuestión que aquí nos interesa, y trajo más ruido conceptual a

\footnotetext{
14 Adoptada en Bogotá (Colombia) el 30 de marzo de 1948. Los treinta y cinco Estados independientes de América son miembros de la Organización de los Estados Americanos y se hallan, por lo tanto, bajo la órbita de la Declaración: Antigua y Barbuda, Argentina, Bahamas, Belice, Bolivia, Brasil, Canadá, Chile, Colombia, Costa Rica, Cuba, Dominica, Ecuador, El Salvador, Estados Unidos, Grenada, Guatemala, Guyana, Haití, Honduras, Jamaica, México, Nicaragua, Panamá, Paraguay, Perú, República Dominicana, Saint Kitts y Nevis, San Vicente y las Granadinas, Santa Lucía, Suriname, Trinidad y Tobago, Uruguay y Venezuela.

15 Adoptada en San José (Costa Rica) el 22 de noviembre de 1969. Son parte: Argentina, Barbados, Bolivia, Brasil, Chile, Colombia, Costa Rica, Dominica, Ecuador, El Salvador, Granada, Guatemala, Haití, Honduras, Jamaica, México, Nicaragua, Panamá, Paraguay, Perú, República Dominicana, Surinam y Uruguay.

16 Buriano et al. (2008), pp. 101-102.
} 
una materia de por sí compleja. La Declaración Universal de Derechos Humanos de $1948^{17}$ y la Declaración sobre Asilo Territorial de $1967^{18}$ utilizaron ambas la expresión asilo con referencia exclusivamente al asilo territorial. El Pacto Internacional de Derechos Civiles y Políticos, en cambio, no incluyó ninguna disposición relativa al asilo.

El derecho a buscar asilo territorial aparece en el artículo 14 de la Declaración Universal. Aunque la Declaración se refiere al asilo, sin más especificación, se suele entender que lo que se recepta es el asilo territorial: "1. En caso de persecución, toda persona tiene derecho a buscar asilo, y a disfrutar de él, en cualquier país. 2. Este derecho no podrá ser invocado contra una acción judicial realmente originada por delitos comunes o por actos opuestos a los propósitos y principios de las Naciones Unidas".

Paralelamente, el artículo 1 de la Declaración sobre Asilo Territorial de 1967 establece: "1. El asilo concedido por un Estado, en el ejercicio de su soberanía, a las personas que tengan justificación para invocar el artículo 14 de la Declaración Universal de Derechos Humanos, incluidas las personas que luchan contra el colonialismo, deberá ser respetado por todos los demás Estados. 2. No podrá invocar el derecho de buscar asilo, o de disfrutar de éste, ninguna persona respecto de la cual existan motivos fundados para considerar que ha cometido un delito contra la paz, un delito de guerra o un delito contra la humanidad, de los definidos en los instrumentos internacionales elaborados para adoptar disposiciones respecto de tales delitos. 3. Corresponderá al Estado que concede el asilo calificar las causas que lo motivan".

En cambio, en la Convención sobre el Estatuto de los Refugiados de Ginebra de 1951 la terminología es otra. Aquí se habla de refugio para hacer referencia a una forma de protección de carácter territorial. La Convención, es bien conocido, intentó dar una respuesta al problema de las personas que habían buscado protección como consecuencia de la Segunda Guerra Mundial. De allí la limitación de carácter temporal (e incluso geográfico, si los Estados así lo manifestaban) incluida en la definición del concepto de refugiado, que fue eliminada por el Protocolo de 1967 (nos referiremos a esta definición más abajo) ${ }^{19}$. La Convención

\footnotetext{
17 Adoptada por la Asamblea General de las Naciones Unidas en su Resolución 217 A (III), de 10 de diciembre de 1948. Los treinta y cinco Estados independientes de América son miembros de la Organización de las Naciones Unidas y se hallan, por lo tanto, bajo la órbita de la Declaración.

18 Adoptada por la Asamblea General de las Naciones Unidas en su Resolución 2312 (XXII), de 14 de diciembre de 1967. Los treinta y cinco Estados independientes de América son miembros de la Organización de las Naciones Unidas y se hallan, por lo tanto, bajo la órbita de la Declaración.

${ }^{19}$ Convención adoptada por la Conferencia de las Naciones Unidas sobre el Estatuto de los Refugiados y las Personas Apátridas, en Ginebra (Suiza), del 2 al 25 de julio de 1951. Protocolo adoptado en Nueva
} 
y su Protocolo definen quién es un refugiado, cuándo se deja de serlo, cuáles son los derechos y deberes de los refugiados y diversos asuntos de implementación de la protección a los refugiados ${ }^{20}$. Los países latinoamericanos, fieles a la tradición latinoamericana de asilo, se mantuvieron primeramente al margen de esta Convención, aunque luego fueron incorporándose lentamente a ella.

Como ya dijimos, una de las situaciones que produjo la masificación de las personas que buscaban protección internacional fueron las guerras centroamericanas. Teniendo particularmente en cuenta esta situación, en 1985 la Organización de los Estados Americanos adoptó una declaración, conocida como Declaración de Cartagena, por la cual se realizaba una interpretación del alcance del concepto de refugiado en el ámbito americano. La Declaración afirma que, "en vista de la experiencia recogida con motivo de la afluencia masiva de refugiados en el área centroamericana, se hace necesario encarar la extensión del concepto de refugiado". A partir de esta idea, recomienda que en la región se utilice una definición de refugiado "que además de contener los elementos de la Convención de 1951 y el Protocolo de 1967, considere también como refugiados a las personas que han huido de sus países porque su vida, seguridad o libertad han sido amenazadas por la violencia generalizada, la agresión extranjera, los conflictos internos, la violación masiva de los derechos humanos u otras circunstancias que hayan perturbado gravemente el orden público" ${ }^{\prime 21}$. Esta Declaración, aunque es un desarrollo interamericano, pretende ser una adaptación del sistema universal al contexto americano. Y aunque ella no tiene efecto jurídico directo, podría haberse cristalizado como costumbre internacional ${ }^{22}$.

\subsection{La dualidad asilo / refugio}

El desarrollo estratificado del Derecho Internacional en relación con la materia de la protección internacional de personas perseguidas ha dado lugar a una gran controversia en torno del alcance de los conceptos de asilo y refugio.

York (Estados Unidos) el 31 de enero de 1967. Los Estados americanos parte son los siguientes (a falta de aclaración se entiende que en ambos documentos): Antigua y Barbuda, Argentina, Bahamas, Belice, Bolivia, Brasil, Canadá, Chile, Colombia, Costa Rica, Dominica, Ecuador, El Salvador, Estados Unidos (sólo en el Protocolo), Guatemala, Haití, Honduras, Jamaica, México, Nicaragua, Panamá, Paraguay, Perú, República Dominicana, San Vicente y las Granadinas, San Kitts y Nevis (sólo en la Convención), Suriname, Trinidad y Tobago, Uruguay y Venezuela (sólo en el Protocolo).

20 ACNUR (1992), pp. 4-5.

${ }^{21}$ Asamblea General de la OEA: Situación jurídica de los asilados, refugiados y personas desplazadas en el continente americano, punto resolutivo tercero.

${ }^{22}$ Gros (1995). 
A partir de lo que hemos señalado, pueden indicarse tres sistemas referidos a la protección internacional de personas perseguidas.

El sistema de la tradición latinoamericana está conformado por los tratados constitutivos de esta tradición que mencionamos más arriba (principalmente, los de La Habana de 1928, Montevideo de 1933, Montevideo de 1939 y los dos de Caracas de 1954). La protección que se brinda a través de estas convenciones está dirigida principalmente (aunque no únicamente, ya que la redacción de los textos no es uniforme) a los perseguidos por delitos o motivos políticos. La protección diplomática recibe el nombre de asilo o asilo político; la protección territorial, de refugio o asilo territorial.

El sistema universal está conformado por la Declaración Universal de Derechos Humanos, la Declaración sobre Asilo Territorial de 1967 y la Convención sobre el Estatuto de los Refugiados de 1951 y su Protocolo. En todos los casos la única protección contemplada es la territorial. La protección se brinda a quienes sufren persecución (según la Declaración Universal y la Declaración sobre Asilo Territorial) o a quienes sufren persecución o tienen temor fundado de ser perseguidos por determinadas circunstancias (según la Convención sobre el Estatuto de los Refugiados y su Protocolo). Mientras que en los dos primeros documentos se utiliza la expresión asilo, el tercer documento y su Protocolo se refieren al refugio y a los refugiados. Lo dicho respecto de la Convención de 1951 y su Protocolo es aplicable a la Declaración de Cartagena que amplía el concepto de refugiado de estos instrumentos en el ámbito americano (como ya vimos, esta Declaración es regional por su ámbito geográfico, pero su contenido corre paralelo a la Convención de 1951 y su Protocolo, ya que se refiere a la aplicación de éstos en el ámbito americano).

Finalmente, el tercer sistema es el Interamericano de Derechos Humanos, conformado por la Declaración y la Convención Americanas. La protección que ambas ofrecen es sólo la territorial, ya sea por cualquier persecución que no sea originada en delito común (Declaración) o por delitos políticos o conexos (Convención). Ambos documentos utilizan la expresión asilo.

Vemos pues que hay una dualidad de términos: asilo y refugio. Se ha indicado que la diferencia entre uno y otro es que el asilo se otorga para proteger a una persona que es perseguida por delitos políticos, mientras que el refugio tiene una finalidad protectoria más amplia que comprende a cualquier persona perseguida ${ }^{23}$. Esto es acertado como aproximación general, pero no rigurosamente cierto. El asilo de la tradición latinoamericana es otorgado a los perseguidos por delitos políticos o conexos, pero también por otras razones en algunos casos. En la redacción literal de la Convención Americana el asilo está también referido a

${ }^{23}$ O’Donnell (2012), p. 637; Fischel de Andrade (2001), p. 99; Ruiz de Santiago (1991), pp. 24-101. 
los perseguidos por delitos políticos, aunque como veremos una interpretación más amplia es posible y de hecho ha sido avalada por la Corte Interamericana. Por otra parte, cuando la palabra asilo es usada en el sistema universal aplica a diversos casos de persecución; y en la Declaración Americana a cualquier caso de persecución que no sea motivada en delito común. Por otra parte, es verdad que el refugio de la Convención de 1951 ofrece una protección más amplia que el asilo de la tradición latinoamericana, pero no parece que sea más amplia que el asilo de la Declaración Universal, de la Declaración sobre Asilo Territorial o de los instrumentos interamericanos de Derechos Humanos. La afirmación según la cual el asilo es una institución regional americana mientras que el refugio es una institución universal ${ }^{24}$ también es opinable. Como hemos visto, instrumentos del ámbito universal utilizan el vocablo asilo.

También se ha dicho que el asilo es la institución genérica de protección que incluye tanto el régimen de los refugiados de la Convención de 1951 como el del asilo propiamente dicho de los tratados americanos ${ }^{25}$. Esta distinción está más próxima al uso léxico de los documentos internacionales aunque tampoco es siempre exacta (por ejemplo, porque algunos tratados de la tradición latinoamericana hablan de refugio de modo equivalente a asil $\left.{ }^{26}\right)$.

De lo anterior resulta claro que no es posible distinguir el asilo y el refugio como si fueran dos instituciones distintas y bien delimitadas ${ }^{27}$. Más bien parece que existen múltiples instrumentos de protección internacional de personas perseguidas que tienen grados de obligatoriedad diferente y que guardan complejas relaciones entre sí. El alcance concreto de la protección internacional que un Estado pueda o esté obligado a dar y, en su caso, las características de

\footnotetext{
24 Fischel de Andrade (2001), p. 99; Ruiz de Santiago (1991), pp. 24-101.

25 Declaración de Tlatelolco sobre acciones prácticas en el derecho de los refugiados en América latina y el Caribe (1999), parte II, considerando 6. De hecho, en el mismo documento se dice que refugio y asilo son sinónimos. Más allá del acierto o no de esta posición, no se ve muy bien cómo casa esta sinonimia con la relación de género a especie antes señalada.

${ }^{26}$ Gros (1992), pp. xviii-xx.

27 No resulta aquí de mucha utilidad señalar las múltiples posiciones de los diferentes estudiosos del tema. Sólo nos detendremos en una más, por lo peculiar de su caracterización. El refugio de la Convención de 1951 y su Protocolo de 1967 implicaría un determinado nivel de protección que no significa permitir a los refugiados permanecer en sus territorios indefinidamente. En caso de permitirles la permanencia en el territorio (lo que constituiría el asilo), los Estados se comprometerían a respetar los derechos y obligaciones que establecen la Convención y su Protocolo. El refugio sería un primer paso al goce pleno de los derechos de la Convención y el Protocolo, que constituiría la situación de asilo. En el contexto de la tradición latinoamericana y del sistema interamericano, en cambio, refugio sería equivalente a asilo territorial. A su vez, el asilo del sistema universal y el asilo del sistema interamericano se distinguirían por el alcance menor que tiene este último. Galindo (2002a), pp. 27, 33-35 y 72-73.
} 
los derechos y deberes en cabeza de las personas protegidas dependerán en cada caso de los compromisos internacionales que haya asumido ese Estado. Si para esa protección se utiliza el término asilo o el término refugio también dependerá del contexto convencional en el que esa protección se enmarque, aunque no parece que sea tan importante que se use uno u otro término mientras que el Estado cumpla con sus obligaciones internacionales. Igualmente, si el Estado decide, de modo interno, organizar un sistema unitario de protección internacional o, por el contrario, establecer cauces diferentes (por ejemplo, uno para quienes solicitan protección bajo determinada convención de la tradición latinoamericana y otros para quienes solicitan protección bajo la Convención de 1951) es una cuestión que, aunque por supuesto tiene gran relevancia práctica desde el punto de vista del solicitante de protección, es irrelevante desde la perspectiva internacional mientras el Estado cumpla con sus obligaciones en la extensión debida.

La mayoría de los países americanos no tienen legislaciones con procedimientos específicos para el reconocimiento de la condición de refugiado bajo la Convención de 1951. En estos países, la evaluación de las solicitudes de refugio las realiza el ACNUR, que recomienda al gobierno reconocer o no a la persona en carácter de refugiado. Los países que sí tienen una legislación específica suelen establecer comisiones encargadas de la evaluación de las solicitudes de refugio bajo esta Convención. Si además de este procedimiento existe un cauce diferente para el reconocimiento de un estatuto de protección internacional bajo otro amparo normativo (el Derecho Interamericano de los Derechos Humanos, la tradición latinoamericana de asilo o incluso alguna forma específica de protección reconocida internamente) es una cuestión variable a nivel de los Estados. En algunos casos se observa esa múltiple vía; en otros, los procedimientos para el reconocimiento del estatuto de refugiado bajo la Convención de 1951 absorben a cualesquiera otros que pudieran existir.

En lo que sigue nos referiremos a la institución de protección que estudiamos en este trabajo desde el ángulo del sistema interamericano. Usaremos el término asilo porque éste es el que utilizan los instrumentos interamericanos. Para poder comprender claramente la naturaleza y alcance de este sistema lo pondremos en perspectiva comparada con los otros dos mencionados (el de la tradición latinoamericana y el universal).

\section{Naturaleza del asilo}

\subsection{Relación entre el derecho interamericano y los otros sistemas de protección}

En este apartado abordaremos la relación entre la figura del asilo del Derecho Interamericano de los Derechos Humanos y las figuras de protección equivalentes en la tradición latinoamericana y el sistema universal. 
En el caso de las relaciones entre el sistema interamericano y la tradición latinoamericana, éstas habrán de limitarse a la figura del asilo territorial o refugio reconocido en esta última ya que, como hemos visto, el sistema interamericano sólo reconoce el asilo territorial. El asilo diplomático conlleva otras particularidades y será dejado fuera de nuestro estudio, sin perjuicio de alguna mención incidental cuando resulte útil.

Aún restringidas de este modo, sin embargo, no parece que exista hoy una interacción profunda entre el Derecho Interamericano de los Derechos Humanos y la tradición latinoamericana de asilo. Es verdad que de los pronunciamientos más antiguos de la Comisión parece seguirse que las normas del Derecho Interamericano de los Derechos Humanos deben interpretarse a la luz de la tradición latinoamericana ${ }^{28}$. Sin embargo, a partir de la década de los 90, la Comisión tiende a interpretar los instrumentos interamericanos a la luz del Derecho Internacional de los Refugiados ${ }^{29}$. La Corte Interamericana, por su parte, ha mencionado algunos tratados de la tradición latinoamericana al referirse a los antecedentes de la institución del asilo en América ${ }^{30}$, aunque no parece prestarle demasiada atención como elemento integrador o interpretativo de los instrumentos interamericanos. Es cierto que ha dicho que la remisión a los convenios internacionales en el derecho a buscar y recibir asilo de la Convención y la Declaración Americanas debe entenderse hecha también a las convenciones de la tradición latinoamericana ${ }^{31}$. Pero ha insinuado que los instrumentos de la tradición latinoamericana han cedido en beneficio de la Convención sobre el Estatuto de los Refugiados luego de la entrada en vigor de ésta ${ }^{32}$, a la que la Corte dedica una atención mucho mayor en sus pronunciamientos.

Por ello creemos que, en los hechos y a pesar de la afirmación literal de la Corte, existe una cierta autonomía entre el Derecho Interamericano de los Derechos Humanos y los tratados de la tradición americana. Esta autonomía

${ }^{28}$ Se trataba en general de casos relativos a la negativa del Estado territorial de otorgar salvoconductos para permitir la salida de asilados en embajadas. Ver por ejemplo Comisión IDH: Informe sobre la situación de los Derechos Humanos en Argentina, apartado IV.G. Aunque estamos ante un supuesto de asilo diplomático, y no territorial, resulta interesante de igual modo referenciar el criterio interpretativo de la Comisión.

29 Cantor y Barichello (2014), p. 698; Cantor y Barichello (2013), pp. 698-699.

30 Corte IDH: Familia Pacheco Tineo, párr. 137. Corte IDH: Derechos y garantías de niñas y niños en el contexto de la migración y/o en necesidad de protección internacional, párr. 74.

${ }^{31}$ Corte IDH: Derechos y garantías de niñas y niños en el contexto de la migración y/o en necesidad de protección internacional, párr. 78.

${ }^{32}$ Corte IDH: Derechos y garantías de niñas y niños en el contexto de la migración y/o en necesidad de protección internacional, párr. 74. 
de los sistemas puede entenderse si se tiene en cuenta que la tradición latinoamericana no está configurada bajo la lógica de la protección de los Derechos Humanos, sino bajo la lógica de las relaciones interestatales. Por esta misma razón se entiende que la interacción entre el sistema interamericano y el sistema universal, que también funciona bajo la lógica de los derechos de los individuos, sea mucho más profunda. De hecho, la tendencia general en esta materia es la de aproximar el asilo interamericano a las figuras del sistema universal, hasta confundirlas en una sola ${ }^{33}$.

La Corte Interamericana, desde sus primeros pronunciamientos, ha recogido la tendencia a integrar las normas del sistema regional de protección de los Derechos Humanos con otras normas provenientes del sistema universal ${ }^{34}$. En una línea semejante, la Comisión, refiriéndose al caso particular del Derecho Humanitario, ha dicho que cuando existen diferencias entre las normas legales que rigen derechos idénticos o similares en la Convención Americana y en un instrumento de Derecho Humanitario, la Comisión está obligada a asignar efecto legal a las disposiciones del tratado con el estándar más elevado ${ }^{35}$.

La Comisión también ha afirmado que las normas del Derecho Internacional de los Refugiados, las normas del Derecho Internacional de los Derechos Humanos y las normas del Derecho Internacional Humanitario se complementan recíprocamente ${ }^{36}$. Y que por esta razón al interpretar las normas de la Declaración Americana (nosotros agregamos: y de la Convención Americana) a la luz de otras normas del Derecho Internacional, la Comisión actúa dentro de su mandato ${ }^{37}$. Siguiendo esta interpretación integradora, la Comisión ha llevado los estándares de protección más allá de lo estrictamente previsto en el Derecho Internacional de los Refugiados ${ }^{38}$. Esta práctica de la Comisión ha recibido la aprobación de la Corte $^{39}$.

${ }^{33}$ Ver en este sentido la sugerencia de las Conclusiones y recomendaciones del coloquio sobre el asilo y la protección internacional de refugiados en América Latina.

${ }^{34}$ Corte IDH: Otros tratados: objeto de la función consultiva de la Corte, Opinión Consultiva OC 1/82 de 24 de septiembre de 1982, Serie A Nº 1, párr. 41.

35 Comisión IDH: Abella (Argentina), párr. 165-166.

${ }^{36}$ Comisión IDH: Informe sobre la situación de los derechos humanos de los solicitantes de asilo en el marco del sistema canadiense de determinación de la condición de refugiado, párr. 26-28.

37 Comisión IDH: Informe sobre la situación de los derechos humanos de los solicitantes de asilo en el marco del sistema canadiense de determinación de la condición de refugiado, párr. 38.

${ }^{38}$ En particular, por el alcance que ha dado a la protección complementaria, como derivada del principio de non-refoulement. Cantor y Barrichello (2013), p. 695.

${ }^{39}$ Corte IDH: Otros tratados: objeto de la función consultiva de la Corte, párr. 43. 
La convergencia entre el Derecho Interamericano de los Derechos Humanos y otras ramas del Derecho Internacional, como el Derecho Internacional de los Refugiados, ha sido también reconocida por la doctrina ${ }^{40}$.

En la primera sentencia dictada por la Corte Interamericana en relación con el asilo, el caso Familia Pacheco Tineo, la Corte tiende a identificar la figura del asilo territorial de la Convención y la Declaración Americanas con la del refugio del sistema universal, fundiendo las normas relativas a una y otra para interpretarlas conjuntamente ${ }^{41}$. Sin embargo, en algunos pasajes parece indicar que el asilo no se confunde totalmente con el refugio, sino que es una dimensión o parte de él: "la institución del asilo, que es una emanación directa del derecho a buscar asilo y a disfrutar de él, enunciado en el párrafo 1 del artículo 14 de la Declaración Universal de Derechos Humanos de 1948, es uno de los mecanismos más fundamentales para la protección internacional de los refugiados ${ }^{\prime 42}$. A pesar de la imprecisión conceptual de la Corte en este punto, por otra parte usual en los pronunciamientos en materia migratoria ${ }^{43}$, parece que el espíritu general del pronunciamiento es el de identificar ambas expresiones.

La identidad entre ambas figuras encuentra sustento tanto en los artículos 22.7 de la Convención y XVII de la Declaración (que mencionan expresamente otras fuentes del Derecho Internacional) como en el artículo 29.b de la Convención según el cual ésta no puede ser interpretada en el sentido de "limitar el goce y ejercicio de cualquier derecho o libertad que pueda estar reconocido de acuerdo con las leyes de cualquiera de los Estados Partes o de acuerdo con otra convención en que sea parte uno de dichos Estados" ${ }^{\prime 4}$.

La misma tendencia a aproximar ambas instituciones se verifica en la Opinión Consultiva sobre los menores migrantes ${ }^{45}$. En razón de una interpretación de la normativa americana que esté en concordancia con otras fuentes internaciona-

40 Piza y Cisneros (1982), p. 110; Cançado (1996), p. 166; San Juan y Manly (2004), pp. 57-59; Gros (1978).

${ }^{41}$ La Corte también menciona el asilo de la Declaración Universal de los Derechos Humanos como equivalente al asilo de los instrumentos interamericanos. Sin embargo, ella no presta atención a la Declaración sobre Asilo Territorial de 1967. En cualquier caso, no parece que esto cambie mucho la consideración de fondo. Esta Declaración carece del carácter normativo de un tratado y no tiene la fuerza moral de la Declaración Universal de Derechos Humanos.

42 Corte IDH: Familia Pacheco Tineo, párr. 142.

43 Arlettaz (2013), pp. 247-260.

${ }^{44}$ Corte IDH: Familia Pacheco Tineo, párr. 143.

${ }^{45}$ Corte IDH: Derechos y garantías de niñas y niños en el contexto de la migración y/o en necesidad de protección internacional, párr. 73. 
les, la Corte señala que el derecho a buscar y recibir asilo abarca el refugio del sistema universal ${ }^{46}$. En el caso americano, también tienen derecho las personas incluidas en la definición de la Declaración de Cartagena ${ }^{47}$.

\section{2. ¿Un verdadero derecho?}

La segunda pregunta que surge en relación con el asilo es si existe un derecho a obtenerlo o si su reconocimiento es un acto discrecional del Estado y sólo existe un derecho a buscarlo, pero no a obtenerlo. La existencia de un derecho a obtener asilo implicaría que, si se da efectivamente una situación de persecución, el Estado solicitado no podría denegar la protección.

Se impone aquí la realización de una distinción fundamental entre dos grupos de normas relativas al asilo. Por un lado, aquellas que se insertan en una lógica de relaciones interestatales, regulando la posición del Estado que otorga el asilo en relación con otros Estados interesados (principal, aunque no exclusivamente, el Estado de la nacionalidad del asilado). Por otro lado, aquellas que pertenecen al ámbito del Derecho Internacional de los Derechos Humanos. En la primera categoría se ubican los tratados de la tradición latinoamericana; en la segunda, los instrumentos del sistema universal y del sistema interamericano de Derechos Humanos.

En el contexto de las normas sobre el asilo basadas en la lógica interestatal parece claro que otorgar el asilo (no sólo el diplomático, sino incluso el territorial al que aquí nos referimos) es un derecho del Estado, pero recibirlo no es un derecho del individuo perseguido. Ésta es la concepción del asilo propia de la tradición latinoamericana ${ }^{48}$. Así, por ejemplo, las dos Convenciones de Caracas parecen decantarse por esta opción, refiriéndose a un derecho del Estado de otorgar el asilo, pero no a un derecho del individuo a obtenerlo ${ }^{49}$.

\footnotetext{
${ }^{46}$ Corte IDH: Derechos y garantías de niñas y niños en el contexto de la migración y/o en necesidad de protección internacional, párr. 78.

${ }^{47}$ Corte IDH: Derechos y garantías de niñas y niños en el contexto de la migración y/o en necesidad de protección internacional, párr. 79.

48 Galindo (2002a), p. 42.

49 Sin embargo, aunque el artículo II de la Convención de Caracas sobre asilo diplomático señala expresamente que no existe un derecho a recibir asilo, ya que el Estado puede denegarlo libremente y sin necesidad de expresar los motivos de la negativa, la presencia de esta disposición resulta por sí sola altamente significativa. En efecto, ella muestra la existencia de una controversia, al momento de la adopción de la Convención, sobre el carácter de verdadero derecho del asilo, controversia que el instrumento zanja de modo negativo: en tiempos anteriores tal disposición habría sido superflua, ya que nadie dudaba del carácter puramente discrecional del asilo. SAN JuAN y ManLY (2004), p. 55.
} 
Esto resulta claro en las sentencias de la Corte Internacional de Justicia en los casos del derecho de asilo (aunque se trataba de asilo diplomático y no territorial, la mención resulta útil). En estos casos se abordó la situación jurídica creada por el asilo otorgado por Colombia, en sus instalaciones diplomáticas, al político peruano Víctor Haya de la Torre. En ningún momento se mencionó siquiera la posibilidad de que el asilo fuera un derecho del señor Haya de la Torre, si que se trató el caso en el marco de una lógica puramente interestatal ${ }^{50}$.

La lógica de los instrumentos de Derechos Humanos es otra. Aquí sí se reconocen derechos al individuo, aunque la extensión es variable ${ }^{51}$. La Declaración Universal y la Declaración sobre el Asilo Territorial reconocen el derecho a buscar asilo, sin que esto implique un correlativo derecho a recibir asilo ${ }^{52}$.

La Declaración Americana y la Convención Americana, en cambio, hablan de un derecho a buscar y recibir asilo. A primera vista, pues, de la redacción literal de los instrumentos interamericanos de Derechos Humanos parece surgir un verdadero derecho no sólo a pedir, sino a obtener el asilo si se dan las condiciones presupuestas en las respectivas normas. Dado que los instrumentos de Derechos Humanos sólo incorporan el asilo territorial, la existencia de este derecho ha de entenderse limitada a esta forma de protección.

Sin embargo, vista más de cerca, la cuestión no es tan sencilla. Tanto el derecho a buscar como el derecho a recibir asilo vienen condicionados por una cláusula: se puede buscar y recibir asilo de acuerdo con legislación interna y el Derecho Internacional. Esta remisión de los documentos interamericanos a otros sectores normativos parecería llevar a reconocer un derecho condicional: sólo habrá un derecho a buscar o a recibir asilo amparado por los instrumentos interamericanos si el derecho interno y el Derecho Internacional (diferente de la Convención y la Declaración que, obviamente, también son Derecho Internacional) así lo reconocen. De este modo, una violación de la normativa interna o del Derecho Internacional conllevará también una violación de la normativa interamericana.

Sobre el derecho a buscar asilo debe ser mencionado el caso Comité Haitiano de Derechos Humanos, en el que la Comisión abordó la situación de

${ }^{50}$ Corte Internacional de Justicia (CIJ): Asylum case (Colombia v. Perú. CIJ: Haya de la Torre case (Colombia v. Perú).

${ }^{51}$ En el caso particularmente relevante de la Convención sobre el Estatuto de los Refugiados, si bien existe una fuerte corriente de opinión que asume que, aunque no se encuentre expreso en el texto, el derecho a recibir asilo está implícito en la Convención, tal interpretación no es unánime. Ver la discusión en KNEEBONE (2009), pp. 9-11.

52 Galindo (2002), p. 20. 
los haitianos que eran interceptados por Estados Unidos en alta mar (es decir, antes de alcanzar la costa estadounidense) y devueltos a Haití. De acuerdo con la legislación estadounidense, sólo podían solicitar el reconocimiento del estatuto de asilados quienes hubieran Ilegado a territorio de los Estados Unidos. Estados Unidos argumentaba que no había habido violación de la Declaración: según la Declaración, el derecho al asilo se tiene de acuerdo con la legislación nacional, de modo que si la legislación nacional establece que quienes están en alta mar no tienen un derecho a buscar asilo no existe tampoco un derecho amparado por la Declaración.

Sin embargo, la Comisión llegó a la conclusión de que, dado que no se podía establecer de antemano que todas las personas que Estados Unidos interceptaba en alta mar y devolvía a Haití iban a buscar asilo a los Estados Unidos (de hecho, muchos haitianos buscaban asilo en otros países americanos), al impedirles llegar a otros Estados en los que podían haber obtenido protección, los Estados Unidos habían violado el derecho a buscar asilo del artículo XXVII de la Declaración Americana ${ }^{53}$.

El razonamiento de la Comisión parece querer decir que la actitud de los Estados Unidos era ilícita porque impedía a los haitianos llegar a otros lugares donde, de acuerdo con la legislación interna y el Derecho Internacional podrían haber pedido asilo. De este modo, la Comisión parece indicar que, para que exista un derecho a buscar asilo protegido por la Declaración (el mismo criterio podría aplicarse a la Convención), es necesario que ese derecho esté reconocido cumulativamente en el Derecho Internacional y en el derecho interno ${ }^{54}$. Sin embargo, en un caso posterior, la Comisión rectificó (o aclaró) su criterio ${ }^{55}$ : es suficiente que el derecho esté reconocido alternativamente en el derecho internacional o en el derecho interno para que la protección de la Declaración (y de la Convención) se vuelva operativa ${ }^{56}$.

La Corte parece haber ido más lejos al realizar una afirmación que significaría que existe un derecho no condicionado a buscar asilo. Así, en el caso Familia Pacheco Tineo la Corte sostuvo que el derecho de buscar y recibir asilo establecido en el artículo 22.7 de la Convención Americana no asegura que se reconozca el estatuto de refugiado a la persona solicitante, pero sí que su solicitud sea tramitada con las debidas garantías ${ }^{57}$.

${ }^{53}$ Comisión IDH: Comité Haitiano de Derechos Humanos y otros (Estados Unidos), párr. 162-180.

${ }^{54}$ Sandoval (2005), p. 50.

55 Cantor y Barichello (2014), p. 699.

${ }^{56}$ Comisión IDH: John Doe y otros (Estados Unidos), párr. 92.

57 Corte IDH: Familia Pacheco Tineo, párr. 197. 
Mayor dificultad se aprecia en cuanto al derecho a recibir asilo. Si se admite que éste existe verdaderamente, el individuo debería verse reconocido con el estatuto de asilado en cualquier caso en el que estuviesen dadas las condiciones para que el mismo sea concedido. Sin embargo, también aquí resulta aplicable la cláusula que condiciona el derecho a la legislación interna y al Derecho Internacional. Por ello, parece que la interpretación correcta es que existiría un derecho a recibir asilo a condición de que exista un Estado que esté dispuesto a otorgarlo. De hecho, la existencia de una costumbre bien consolidada respecto de la potestad discrecional del Estado para conferir el asilo no parece que pueda ser dejada de lado por el lenguaje no del todo preciso de la Declaración y la Convención ${ }^{58}$.

Esta interpretación es coincidente con la afirmación de la Comisión en el ya nombrado caso del Comité Haitiano de Derechos Humanos, en el que dijo que si el derecho de una persona a recibir asilo está amparado por el Derecho Internacional pero no está reconocido en el derecho interno, tal derecho no está protegido por la Declaración ${ }^{59}$. Aunque la Comisión se refería a la Declaración, el mismo razonamiento sería extensible a la Convención. Sin embargo, como ya hemos visto, la Comisión rectificó luego su criterio, en lo relativo al derecho a buscar asilo. Aunque en el mencionado caso $^{60}$ la Comisión no se refirió al derecho a recibir asilo, es razonable pensar que el mismo criterio interpretativo (que es suficiente que el derecho esté reconocido en el Derecho Internacional o en la legislación interna, pero no es necesario que lo esté en ambos) podría aplicarse. En este mismo sentido, en informes posteriores la Comisión afirmó que la condición de refugiado se deriva de las circunstancias de la persona, de modo que no es otorgada por el Estado sino simplemente reconocida por este. El propósito de los procedimientos aplicables, entonces, es garantizar que la protección internacional sea reconocida en todos los casos en que se justifique ${ }^{61}$.

La Corte Interamericana, por su parte, parece realizar afirmaciones contradictorias. En el caso Familia Pacheco Tineo la Corte no sólo dijo que los instrumentos interamericanos no aseguran que un solicitante de asilo reciba la protección que busca ${ }^{62}$, sino que además dejó claramente sentado que no

\footnotetext{
58 Galindo (2002a), p. 65.

59 Comisión IDH: Comité Haitiano de Derechos Humanos y otros, párr. 151-153.

60 Comisión IDH: John Doe y otros (Estados Unidos).

61 Comisión IDH: Informe sobre la situación de los derechos humanos de los solicitantes de asilo en el marco del sistema canadiense de determinación de la condición de refugiado, párr. 70. Comisión IDH: Informe sobre terrorismo y derechos humanos, párr. 394. Comisión IDH: Derechos humanos de los migrantes y otras personas en el contexto de la movilidad humana en México, párr. 545.

62 Corte IDH: Familia Pacheco Tineo, párr. 197.
} 
le correspondía hacer una evaluación de la procedencia de la solicitud de asilo, que es competencia de las autoridades nacionales. La Corte recordó que el derecho a buscar y recibir asilo, según reconocen la Convención y la Declaración Americanas, se tiene de acuerdo con la legislación nacional63. Esta primera afirmación sugiere lo mismo que había dicho la Comisión en un primer momento: si la legislación nacional no reconoce el asilo a una persona en un determinado supuesto no habría un derecho reconocido por el sistema interamericano a conseguir asilo.

Sin embargo, esta afirmación de la Corte debe compatibilizarse con otras dos. Por un lado, ella ha dicho que le corresponde determinar si las actuaciones de las autoridades nacionales han sido compatibles con los estándares internacionales. En efecto, la Corte dijo en Familia Pacheco Tineo y en la Opinión Consultiva sobre niñez migrante que la solicitud de asilo debe ser considerada con las debidas garantías ${ }^{64}$. Por otro lado, la Corte fue más allá y afirmó en la Opinión Consultiva sobre niñez migrante que la concesión de asilo no puede considerarse una mera prerrogativa estatal (como es considerada en las convenciones de la tradición latinoamericana), sino que existe un derecho subjetivo a recibir asilo $^{65}$. Y, como ya hemos dicho, en ambos pronunciamientos conectó la mención de los convenios internacionales de los artículos XXVII de la Convención y 22.7 de la Declaración a los tratados de la tradición latinoamericana y a los instrumentos del sistema universal.

Puede ensayarse la siguiente aproximación para compatibilizar las afirmaciones aparentemente contradictorias de la Corte. El derecho a recibir asilo sólo se tiene si la legislación nacional lo reconoce. Sin embargo, la legislación nacional no puede establecer a su antojo los supuestos en los que reconocerá un derecho a recibir asilo, sino que debe ceñirse a los instrumentos internacionales mencionados. Sin embargo, y a pesar de lo que la Corte literalmente dice, las restricciones sobre la potestad legislativa estatal provendrán de los instrumentos del sistema universal, porque los instrumentos de la tradición latinoamericana, al configurar el asilo como una potestad soberana del Estado, dejan abierto el camino a la discrecionalidad estatal.

\footnotetext{
${ }^{63}$ Corte IDH: Familia Pacheco Tineo, párr. 143.

${ }^{64}$ Corte IDH: Familia Pacheco Tineo, párr. 154-155. Corte IDH: Derechos y garantías de niñas y niños en el contexto de la migración y/o en necesidad de protección internacional, párr. 81 y ss. y 108 y ss.

${ }^{65}$ Corte IDH: Derechos y garantías de niñas y niños en el contexto de la migración y/o en necesidad de protección internacional, párr. 73. Al afirmar la existencia de este verdadero derecho subjetivo la Corte remite a su posición en Corte IDH: Familia Pacheco Tineo, párr. 137-140. Sin embargo, en este lugar la Corte no dijo lo que luego dice que dijo, sino que fue mucho más ambigua.
} 
De este modo, la Corte podrá hallar una violación del derecho a recibir asilo si la legislación de un Estado excluye del derecho a recibir asilo a quien goza de él según el Derecho Internacional o si en la evaluación de la solicitud de asilo se han violado las reglas del debido proceso. Pero supuesto que la legislación interna ha pasado el test del Derecho Internacional y que las garantías en la evaluación de la solicitud han sido respetadas, la Corte no puede entrar a evaluar el mérito de la decisión interna.

Esta conclusión se ve reafirmada por la posición adoptada por la Corte en la Opinión Consultiva sobre los menores migrantes, en la que sostuvo que si bien existe un verdadero derecho a buscar y recibir asilo ${ }^{66}$ la determinación de los supuestos en los que se ejerce el derecho depende de la legislación de cada país (se entiende, del país en el que se solicita la protección internacional) y de los convenios internacionales, según los artículos 22.7 de la Convención y XXVII de la Declaración ${ }^{67}$.

Este punto de vista ya había sido anticipado en un voto concurrente del juez Cançado Trindade, que había promovido la consideración del derecho al asilo como un verdadero derecho individual y no como una mera facultad del Estado. Aunque reconocía que no era éste todavía el estado del derecho internacional vigente, sino que se trataba de un derecho en formación: "El corpus juris del Derecho Internacional de los Derechos Humanos contiene, en efecto, elementos que pueden conllevar a la construcción (o quizás reconstrucción) de un verdadero derecho individual al asilo" ${ }^{\prime \prime 8}$. Este derecho se encuadraría en el marco de un verdadero derecho humano a la asistencia humanitaria que estaría también en formación ${ }^{69}$. Según el juez, esta comprensión del derecho de asilo podría encontrar amparo en el artículo 22 de la Convención Interamericana ${ }^{70}$.

Como dijimos, la evaluación de las solicitudes de asilo debe respetar el debido proceso. Esto significa que el derecho de buscar y recibir asilo establecido en el artículo 22.7 de la Convención debe ser leído en conjunto con los

${ }^{66}$ Corte IDH: Derechos y garantías de niñas y niños en el contexto de la migración y/o en necesidad de protección internacional, párr. 73.

${ }^{67}$ Corte IDH: Derechos y garantías de niñas y niños en el contexto de la migración y/o en necesidad de protección internacional, párr. 74.

${ }^{68}$ Corte IDH: Condición jurídica y derechos de los migrantes indocumentados, voto concurrente del juez Cançado Trindade, párr. 38.

${ }^{69}$ Corte IDH: Condición jurídica y derechos de los migrantes indocumentados, voto concurrente del juez Cançado Trindade, párr. 38.

${ }^{70}$ Corte IDH: Condición jurídica y derechos de los migrantes indocumentados, voto concurrente del juez Cançado Trindade, párr. 38. 
artículos 8 y 25 de la misma, que establecen respectivamente las garantías del debido proceso y el derecho a un recurso judicial ${ }^{71}$. Lo mismo debe decirse del derecho semejante reconocido en el artículo XXVII de la Declaración. "[...] Todo procedimiento relativo a la determinación de la condición de refugiado de una persona implica una valoración y decisión sobre el posible riesgo de afectación a sus derechos más básicos, como la vida, la integridad y la libertad personal. De tal manera, aun si los Estados pueden determinar los procedimientos y autoridades para hacer efectivo ese derecho, en aplicación de los principios de no discriminación y debido proceso, se hacen necesarios procedimientos previsibles, así como coherencia y objetividad en la toma de decisiones en cada etapa del procedimiento para evitar decisiones arbitrarias" $^{\prime 72}$.

En un sentido semejante se ha pronunciado la Comisión Interamericana, para la cual "el proceso para determinar quién es o quién no es un refugiado implica hacer determinaciones caso por caso que pueden influir en la libertad, la integridad personal e inclusive la vida de la persona de que se trate" por lo que "los principios básicos de igual protección y debido proceso [...] hacen necesarios procedimientos previsibles y coherencia en la toma de decisiones en cada etapa del proceso"73.

En el caso Familia Pacheco Tineo la Corte halló una violación de las garantías procesales aplicables a la evaluación de solicitudes de asilo. Las autoridades bolivianas habían determinado sumariamente que no darían curso a la solicitud de asilo presentada por la familia Pacheco, y lo habían hecho sin dar audiencia a los interesados ${ }^{74}$. El argumento dado por la resolución era que habían cesado las causas de persecución en Perú, ya que el señor Pacheco había renunciado al estatuto de refugiado que le había sido otorgado en una situación anterior por Bolivia y había regresado a Perú ${ }^{75}$. Según la Corte, esta actitud de Bolivia implicaba no tener en cuenta la posibilidad de que las circunstancias hubiesen cambiado porque se hubiesen producido hechos sobrevinientes a tal renuncia ${ }^{76}$. Por otro lado, Bolivia había alegado que se había tratado de un procedimiento sumario en razón de que la solicitud era manifiestamente infundada. La Corte, aunque admitió en general la

\footnotetext{
71 Corte IDH: Familia Pacheco Tineo, párr. 154-155.

72 Corte IDH: Familia Pacheco Tineo, párr. 157.

73 Comisión IDH: Informe sobre la situación de los derechos humanos de los solicitantes de asilo en el marco del sistema canadiense de determinación de la condición de refugiado, párr. 52.

74 Corte IDH: Familia Pacheco Tineo, párr. 163.

75 Corte IDH: Familia Pacheco Tineo, párr. 167.

76 Corte IDH: Familia Pacheco Tineo, párr. 173.
} 
posibilidad de que exista un procedimiento sumario, sostuvo que en el caso la autoridad migratoria boliviana no había basado el rechazo en el hecho de que la solicitud era manifiestamente infundada ni había hecho constar las razones por las cuales hubiese llegado a tal conclusión ${ }^{77}$.

La Corte declaró la existencia de una violación del derecho a buscar y recibir asilo (artículo 22.7) y del principio de no devolución (artículo 22.8) en relación con las reglas del debido proceso (artículo 8) ${ }^{78}$. En nuestra opinión, resulta más conveniente caracterizar la actividad del Estado sólo como violación del derecho a buscar y recibir asilo en relación con el debido proceso, pero no del principio de no devolución, ya que la sola negativa al asilo (aunque sea manifiestamente infundada y violatoria de garantías procesales) no constituye una violación del principio de no devolución mientras no haya expulsión del territorio hacia otro territorio donde exista peligro. Es verdad que en el caso la negativa fue seguida de la expulsión del territorio hacia un territorio en el que la familia corría peligro. Pero se trata de dos situaciones conceptualmente distinguibles: la negativa a otorgar asilo que es declarada sin las debidas garantías constituye una violación del artículo 22.7. La expulsión del territorio puede constituir una violación del artículo 22.8.

En la Opinión sobre niñez migrante, a las consideraciones sobre el debido proceso formuladas en Familia Pacheco Tineo, la Corte agregó algunas particularidades relativas a la situación de los menores solicitantes de protección internacional. De acuerdo con la Corte, la evaluación que hagan los Estados sobre la situación de los menores en vista a determinar si requieren protección internacional debe tener por finalidad darles un tratamiento acorde a su condición de tales para adoptar, en caso de ser necesario y pertinente de acuerdo con el interés superior del niño, medidas de protección especial ${ }^{79}$.

La interpretación que venimos haciendo es compatible con, y además depende de, la afirmación de la Corte Interamericana según la cual la Convención de 1951 sobre el Estatuto de los Refugiados, aunque no establece el asilo como un derecho de manera explícita, lo reconoce de modo implícito ${ }^{80}$. Por otra parte, la Corte ha afirmado que el reconocimiento del estatuto de refugiado tiene carácter meramente declarativo, ya que "una persona es un refugiado tan pronto como reúne los requisitos enunciados en la definición" contenida la Convención

\footnotetext{
77 Corte IDH: Familia Pacheco Tineo, párr. 172.

78 Corte IDH: Familia Pacheco Tineo, párr. 180.

79 Corte IDH: Derechos y garantías de niñas y niños en el contexto de la migración y/o en necesidad de protección internacional, párr. 88-107.

${ }^{80}$ Corte IDH: Familia Pacheco Tineo, párr. 139. Este criterio no es unánime. Ver nota 52.
} 
de $1951^{81}$. En un sentido semejante, como ya dijimos, se ha pronunciado la Comisión ${ }^{82}$. Esta es otra de las diferencias entre el régimen universal (y el interamericano, que remite al universal) y el de la tradición latinoamericana, donde la declaración de asilo tiene carácter constitutivo ${ }^{83}$.

\subsection{El principio de no devolución y la naturaleza del asilo}

El principio de no devolución o non-refoulement, como es sabido, prohíbe que una persona sea expulsada al territorio de un Estado en el que corra peligro o que se le impida la entrada a un país dejándolo en el territorio de un Estado en el que corra peligro. Así, la devolución puede tomar la forma de una expulsión o de un rechazo en frontera. Se ha afirmado que el derecho a recibir asilo podría derivarse del principio de no devolución. En este apartado exploraremos esta idea.

La Declaración Americana no contiene una norma que especifique el principio de no devolución. Esta norma, en cambio, sí aparece en la Convención Americana. En los instrumentos del sistema universal, la prohibición de devolución aparece consagrada tanto en la Convención de 1951 como en la Declaración de 1967. Los instrumentos de la tradición latinoamericana, por su parte, fieles a la concepción del asilo como una potestad discrecional del Estado, no contienen el principio. El principio también está presente en otros instrumentos no relativos al asilo, como la Convención contra la Tortura de 1984 (artículo 3) y la Convención Interamericana para Prevenir y Sancionar la Tortura de 1985 (artículo 13). El principio es además una norma de derecho internacional consuetudinario, según lo reconoce la doctrina ${ }^{84}$.

Comencemos por los instrumentos del sistema universal. El artículo 31.1 de la Convención sobre el Estatuto de los Refugiados dispone: "Ningún Estado Contratante podrá, por expulsión o devolución, poner en modo alguno a un refugiado en las fronteras de los territorios donde su vida o su libertad peligre por causa de su raza, religión, nacionalidad, pertenencia a determinado grupo social, o de sus opiniones políticas". Así, según el principio de no devolución, la persona tiene derecho a no ser devuelto a aquel país donde su vida o libertad peligren, lo que implica que tiene derecho a permanecer en

\footnotetext{
81 Corte IDH: Familia Pacheco Tineo, párr. 151.

82 Comisión IDH: Informe sobre la situación de los derechos humanos de los solicitantes de asilo en el marco del sistema canadiense de determinación de la condición de refugiado, párr. 70.

83 Galindo (2002a), p. 78; Fischel de Andrade (1999), p. 99; Ruiz de Santiago (1991), pp. 24-101.

${ }^{84}$ Goodwin Gill (1978), p. 142; ACNUR (2013).
} 
el país en el que se encuentra o a ser reasentado en un tercer país seguro ${ }^{85}$. El mismo principio aparece en el artículo 3.1 de la Declaración de 1967 sobre Asilo Territorial: "Ninguna de las personas a que se refiere el párrafo 1 del artículo 1 será objeto de medidas tales como la negativa de admisión en la frontera o, si hubiera entrado en el territorio en que busca asilo, la expulsión o la devolución obligatoria a cualquier Estado donde pueda ser objeto de persecución" ${ }^{86}$.

Según está establecido en la Convención de 1951, el principio de no devolución prohíbe tanto la expulsión del territorio (incluida la extradición) como el rechazo en frontera; $y$, dado que el reconocimiento del carácter de refugiado es meramente declarativo, incluye a quien ha sido reconocido formalmente como refugiado y a quienes califican como tales a la luz de la Convención de 1951, aunque no hayan recibido ese reconocimiento formal ${ }^{87}$. El principio exige que antes de expulsar o rechazar a un extranjero se realice un análisis individualizado del caso, y se aplica incluso en el contexto de flujos masivos ${ }^{88}$. Por otra parte, el principio ampara contra cualquier acto imputable a un Estado, aunque sea cometido fuera de su territorio e incluye también la devolución indirecta ${ }^{89}$.

Del principio de no devolución algunos autores han derivado el derecho a recibir protección en el contexto de los instrumentos universales ${ }^{90}$. Dado que la definición de refugiado tiene carácter declarativo, toda persona que reúna las condiciones enunciadas califica automáticamente como tal. Y dado que califica, no puede ser rechazado en frontera o expulsado. Luego, tiene un derecho a recibir refugio.

La Corte Interamericana se cuenta entre quienes reconocen implícito tal derecho a recibir protección. Aunque la Corte reconoce que el derecho a recibir asilo no está explícito en la Convención de 1951, sostiene que "se considera incorporado de manera implícita en su texto, el cual menciona la definición

85 O’Donnell (2012), p. 638.

86 El segundo inciso del artículo dispone: "Sin embargo, no podrá invocar los beneficios de la presente disposición el refugiado que sea considerado, por razones fundadas, como un peligro para la seguridad del país donde se encuentra, o que, habiendo sido objeto de una condena definitiva por un delito particularmente grave, constituya una amenaza para la comunidad de tal país".

87 Lauterpacht y Bethlehem (2001), pp. 24-31.

88 Lauterpacht y Bethlehem (2001), pp. 33-39.

89 Lauterpacht y Bethlehem (2001), pp. 24 y 39.

90 O’Donnell (2012), p. 638. 
de refugiado, la protección contra el principio de no devolución y un catálogo de derechos a los que tienen acceso los refugiados" ${ }^{\prime \prime 1}$.

Sin embargo, el argumento anterior no es compartido por todos. De hecho, resulta acertada la posición de quienes dicen que de la obligatoriedad del principio de no devolución no se sigue que exista un derecho a recibir asilo. El Estado puede cumplir con la no devolución y no otorgar asilo, por ejemplo reasentando a la persona en un tercer país seguro u otorgando algún otro tipo de protección (como por ejemplo una protección temporaria) ${ }^{92}$. Hay un campo de superposición parcial entre la figura del asilo y la de la prohibición de devolución ${ }^{93}$. En efecto, si el Estado concede asilo, no puede expulsar al asilado a un territorio donde corra peligro. De hecho, no puede expulsar al extranjero de su territorio con destino a cualquier otro país, corra o no peligro en él, sin revocar antes el asilo otorgado. Si lo hiciera estaría desconociendo el asilo que él mismo había otorgado (y violando además el principio de no devolución si la expulsión fuera a un país de riesgo). Ahora bien, si se admite que en algunos casos recibir asilo puede ser un verdadero derecho del individuo, el Estado no podrá revocar el asilo (ni denegar una solicitud, claro) de modo puramente discrecional.

Pero las figuras no se superponen totalmente: incluso si el Estado no concede asilo, o si lo concede y luego lo revoca legítimamente, está obligado por el principio de no devolución. En este caso, el Estado debería conceder a la persona otro título para permanecer en su territorio, entregarla a otro Estado donde ella pudiera buscar protección o al menos permitir que saliera hacia ese Estado. Sólo de este modo, aunque no reconociera el asilo pedido o revocara un asilo ya concedido, no habría violación del principio de no devolución. Existe pues una relativa independencia entre la protección del asilo (o refugio) y el principio de no devolución.

Veamos ahora el plano del sistema interamericano. El principio de no devolución aparece en el artículo 22.8 de la Convención Americana. La disposición establece: "En ningún caso el extranjero puede ser expulsado o devuelto a otro país, sea o no de origen, donde su derecho a la vida o a la libertad personal está en riesgo de violación a causa de raza, nacionalidad, religión, condición social o de sus opiniones políticas". Aunque la Declaración Americana no lo menciona expresamente, la Comisión lo ha reconocido como

91 Corte IDH: Familia Pacheco Tineo, párr. 136. Corte IDH: Derechos y garantías de niñas y niños en el contexto de la migración y/o en necesidad de protección internacional, párr. 139.

92 Lauterpacht y Bethlehem (2001), pp. 26-31.

${ }_{93}$ Arlettaz (2015). 
implícito en ella, como una derivación del derecho a buscar y recibir asilo en relación con los derechos a la vida, a la libertad y a la integridad personal ${ }^{94}$. La Corte Interamericana ha admitido que es también un principio de derecho consuetudinario ${ }^{95}$.

Tanto la Comisión Interamericana como la Corte Interamericana han reconocido que la protección emergente del principio de no devolución se aplica a todos los extranjeros, con independencia de su situación a la luz de la normativa interna de extranjería. Por ello, cuando un extranjero alegue ante un Estado un riesgo en caso de devolución, las autoridades competentes de ese Estado deberán entrevistar a la persona y realizar una evaluación preliminar, a efectos de determinar si existe ese riesgo ${ }^{96}$. En caso de menores, los riesgos deben ser analizados con un enfoque de edad y de género, así como dentro de la lógica establecida por la propia Convención sobre los Derechos del Niño ${ }^{97}$.

El carácter amplio del reconocimiento implica que están beneficiadas por el principio de no devolución aquellas personas que ya se encuentran en el territorio del Estado (gozando del estatuto de asilado, de otro título jurídico que les permite estar en ese territorio o incluso careciendo de todo título jurídico) y quienes pretenden entrar al territorio del Estado (califiquen o no como eventuales asilados ${ }^{98}$. Además, el principio de no devolución debe ser respetado por el Estado en cualquier caso en que éste ejerza su jurisdicción, incluso si se trata de un ejercicio no territorial ${ }^{99}$.

Esto quiere decir que la protección se aplica no sólo a quienes ya tienen reconocido el estatuto de asilado o refugiado, sino también, y fundamentalmente, a quienes solicitan tal reconocimiento, mientras su situación no haya sido

${ }^{94}$ Comisión IDH: Informe sobre la situación de los derechos humanos de los solicitantes de asilo en el marco del sistema canadiense de determinación de la condición de refugiado, párr. 32.

${ }^{95}$ Corte IDH: Familia Pacheco Tineo, párr. 151.

${ }_{96}$ Corte IDH: Familia Pacheco Tineo, párr. 135-136. Corte IDH: Derechos y garantías de niñas y niños en el contexto de la migración y/o en necesidad de protección internacional, párr. 210. Comisión IDH: Informe sobre la situación de los derechos humanos de los solicitantes de asilo en el marco del sistema canadiense de determinación de la condición de refugiado, párr. 25 y 111. Comisión IDH: Informe sobre terrorismo y derechos humanos, párr. 394.

${ }^{97}$ Corte IDH: Derechos y garantías de niñas y niños en el contexto de la migración y/o en necesidad de protección internacional, párr. 222.

${ }_{98}$ Corte IDH: Familia Pacheco Tineo, párr. 136. Corte IDH: Derechos y garantías de niñas y niños en el contexto de la migración y/o en necesidad de protección internacional, párr. 210-215. Comisión IDH: Informe sobre terrorismo y derechos humanos, párr. 394.

99 Corte IDH: Derechos y garantías de niñas y niños en el contexto de la migración y/o en necesidad de protección internacional, párr. 219. 
particularmente considerada. La prohibición de devolución incluye también la devolución indirecta, que es aquella que se produce cuando el individuo es expulsado hacia un país que luego lo transferirá a un tercer país donde existe riesgo de persecución ${ }^{100}$.

La relativa independencia entre el asilo y la prohibición de devolución de la que hablamos antes fue reconocida por la Corte Interamericana, que como ya dijimos ha afirmado que el principio de no devolución beneficia a los asilados reconocidos, a aquellos que califiquen como tales aunque todavía no hayan sido reconocidos en este carácter y a los solicitantes de asilo; y que incluso beneficia a quienes no han sido reconocido como asilados, no califican como tales ni han solicitado tal reconocimiento. Esto último se deriva de que en razón de la interpretación literal del artículo 22.8 de la Convención habría que admitir que el principio de no devolución es independiente de la existencia de una medida de protección internacional o de una solicitud de protección internacional ${ }^{101}$. Según la Corte, en aquellos casos en que una persona no califique como asilado pero no sea posible su expulsión en razón del principio de no devolución, correspondería recurrir a otro tipo de medida, en general conocida bajo el nombre de protección complementaria ${ }^{102}$. Parece entonces que este sería un punto que diferencia al régimen interamericano de no devolución del régimen de no devolución de la Convención de 1951: en esta última, la prohibición de devolución se aplica a quienes califiquen como refugiados, mientras que en el sistema interamericano la no devolución es independiente de una eventual calificación como asilado.

La perspectiva de la Corte debe matizarse. Es verdad que el principio de no devolución de la Convención Americana es más amplio que el derecho de asilo literalmente reconocido en la misma Convención. El derecho de asilo se otorga por "delitos políticos o comunes conexos"; la prohibición de devolución se aplica en cualquier situación en la que su "derecho a la vida o a la libertad personal está en riesgo de violación a causa de raza, nacionalidad, religión, condición social o de sus opiniones políticas". Sin embargo, una vez que se interpreta, como hace la Corte, el derecho de asilo como incluyendo las causas de persecución de la Convención de 1951 (e incluso la más genérica causal mencionada en la Declaración Americana), las diferencias se difuminan un poco. Las personas que están amparadas por el principio de no devolución

${ }^{100}$ Corte IDH: Familia Pacheco Tineo, párr. 153.

101 Corte IDH: Derechos y garantías de niñas y niños en el contexto de la migración y/o en necesidad de protección internacional, párr. 215.

102 Corte IDH: Derechos y garantías de niñas y niños en el contexto de la migración y/o en necesidad de protección internacional, párr. 238. 
reconocido en la Convención Americana, aunque no califiquen directamente como asilados según la dicción literal de la Convención Americana, pueden calificar como refugiados bajo la Convención de 1951 o como personas con derecho a asilo bajo la Declaración Americana y entonces, indirectamente, calificar como personas con derecho asilo bajo la Convención Americana (volveremos sobre este punto un poco más abajo).

Donde sí pueden apreciarse algunas diferencias es en el hecho de que la Convención de 1951 establece algunas excepciones posibles al principio de no devolución ${ }^{103}$. La Convención Americana, en cambio, no contiene tales excepciones. Así, lleva razón la Corte cuando dice que en el sistema interamericano, el principio de no devolución es más amplio en su sentido y alcance que en el Derecho Internacional de los Refugiados; aunque quizá no tanto por la alegada complementariedad que operaría en la aplicación del Derecho Internacional de Refugiados y el Derecho Internacional de los Derechos Humanos ${ }^{104}$, sino por la propia configuración literal de las disposiciones involucradas. Aunque la Corte no parece querer decir que el principio de no devolución sea absoluto bajo el régimen interamericano (y la Comisión, como veremos luego, ha declarado que las causales de exclusión de la Convención de 1951 se aplican en el contexto interamericano), el hecho de que la Convención no reconozca expresamente excepciones no deja de ser significativo.

Es importante insistir en la diferencia entre el derecho a recibir asilo y la prohibición contra la devolución. En el caso Familia Pacheco Tineo, la Corte constató que el Estado no había realizado una determinación adecuada acerca del riesgo al que la expulsión exponía a la familia, por lo que había una violación del derecho a buscar y recibir asilo (artículo 22.7) y del principio de no devolución (artículo 22.8) en relación con las reglas del debido proceso (artículo 8) ${ }^{105}$. Creemos que la Corte incurrió aquí en un error conceptual. En efecto, expulsar a una persona del territorio del Estado sin verificar si esa expulsión puede colocar a esa persona en situación de riesgo implica violar el principio de no devolución, pero no necesariamente el derecho a buscar y recibir asilo (por ejemplo, porque el expulsado nunca pidió asilo, porque lo pidió y su solicitud fue correctamente rechazada, etc.). Es verdad que en el caso, como dijimos más arriba, se daba además una violación del derecho

\footnotetext{
103 Artículo 33.2: "Sin embargo, no podrá invocar los beneficios de la presente disposición el refugiado que sea considerado, por razones fundadas, como un peligro para la seguridad del país donde se encuentra, o que, habiendo sido objeto de una condena definitiva por un delito particularmente grave, constituya una amenaza para la comunidad de tal país".

${ }^{104}$ Corte IDH: Familia Pacheco Tineo, párr. 151.

105 Corte IDH: Pacheco Tineo, párr. 189.
} 
a buscar y recibir asilo. Pero tal violación no provenía de la expulsión, sino del hecho de que el Estado no había considerado con las debidas garantías la solicitud de asilo. Si el Estado hubiese expulsado a la familia con destino a otro país donde no hubiese existido riesgo para ellos se habría mantenido igualmente la violación del derecho a buscar y recibir asilo, pero no habría habido violación del principio de no devolución porque no existía riesgo para los expulsados en ese país ${ }^{106}$.

El riesgo al que podría exponerse el extranjero en caso de ser expulsado o rechazado en la frontera y que habilita el funcionamiento del principio ha sido interpretado en sentido amplio por los órganos interamericanos ${ }^{107}$. La violación del principio de no devolución en razón de un rechazo en frontera puede asumir incluso formas indirectas, como la que se produce cuando un Estado intercepta a un extranjero antes de llegue a la propia frontera y le obliga a regresar al punto de origen. En el ya nombrado caso Comité haitiano de Derechos Humanos, la Comisión declaró que Estados Unidos había cometido una violación del Derecho Internacional al devolver haitianos a Haití sin verificar previamente si existía un riesgo para ellos en el país al que eran devueltos ${ }^{108}$. En la Opinión sobre menores migrantes la Corte se refirió a la interceptación de solicitantes de asilo en aguas internacionales para no permitir que sus peticiones sean evaluadas en potenciales Estados de acogida, entendiendo que esta práctica resulta contraria al principio de no devolución,

106 Por otro lado, en el mismo caso, la Corte constató que la decisión de expulsión había sido expedida en un plazo excesivamente sumario, no había sido notificada y había sido ejecutada inmediatamente. Tal situación había hecho impracticable cualquier recurso interno que, aunque hubiese existido teóricamente, había sido de uso imposible por parte de la familia Pacheco. Estas circunstancias, además de constituir en sí mismas una violación del artículo 8 de la Convención, impidieron a las víctimas el ejercicio de un recurso efectivo para proteger sus derechos y constituyeron por ello también una violación del artículo 25. Corte IDH: Pacheco Tineo, párr. 190-195.

107 Así, la Comisión ha afirmado que el principio se aplica a personas que huyen de situaciones generalizadas de violencia. Comisión IDH: Informe anual 1984-1985, apartado IV (párrafos sin numerar). En el caso Andrea Mortlock la Comisión señaló incluso que la falta de un tratamiento médico adecuado en el país al que se pretendía expulsar al extranjero significaba un riesgo para su integridad y por ello impedía esa expulsión. Comisión IDH Andrea Mortlock (Estados Unidos) Informe de admisibilidad y fondo No. 63/08 de 25 de julio de 2008, caso 12.534. Sin embargo, se trataba de un caso excepcional, ya que la enfermedad era una enfermedad terminal y existían además otras circunstancias que indicaban que la persona expulsada podría sufrir vejaciones en el país de destino. La obligación del Estado no se suspende ni siquiera por el hecho de que existan sospechas de que la persona puede estar implicada en delitos de terrorismo. Comisión IDH: Informe sobre la situación de los derechos humanos de los solicitantes de asilo en el marco del sistema canadiense de determinación de la condición de refugiado, párr. 154.

${ }^{108}$ Comisión IDH: Comité Haitiano de Derechos Humanos y otros. 
pues no permite evaluar los factores de riesgo concretos de cada persona ${ }^{109}$. En otros casos la Comisión también ha pedido a los Estados que se abstengan de devolver a solicitantes de asilo. Así sucedió, por ejemplo, en el caso de los cubanos y haitianos Ilegados a las Bahamas ${ }^{110}$.

\section{Alcance del asilo}

Un punto en el que los instrumentos internacionales son discordantes es el relativo a quiénes pueden beneficiarse de protección internacional. La Declaración Americana tiene una definición muy amplia, que incluye a cualquier persona sometida a "persecución que no sea motivada por delitos de derecho común" (artículo XXVII).

La Convención, en cambio, es decididamente más restrictiva ${ }^{111}$, ya que sólo incluye los casos de "persecución por delitos políticos o comunes conexos con los políticos" (artículo 22.7). Sin embargo, dado que el artículo XXVII de la Declaración no limita el derecho de buscar y recibir asilo a la causal política y que el artículo 29.d de la Convención dispone que ésta no puede interpretarse de modo de "excluir o limitar el efecto que puedan producir la Declaración Americana de Derechos y Deberes del Hombre y otros actos internacionales de la misma naturaleza", hay que concluir que, en el contexto de la Convención, no se puede limitar el asilo únicamente a los casos de persecución política, sino que también se podría aplicar a casos de persecución por motivos religiosos, raciales y, en general, a cualquier otro de los enumerados en el artículo primero de la Convención de 1951112. Más aún: habría que admitir que de los documentos internacionales relevantes habría que aplicar el que diera la protección más amplia, por lo que el asilo podría ser invocado por cualquier persona perseguida, con excepción de los perseguidos por delitos comunes.

En otras palabras: el espectro de personas protegidas por el derecho a buscar y recibir asilo de la Convención debe definirse integrando las definiciones provenientes de otros instrumentos internacionales de Derechos Humanos ${ }^{113}$.

${ }^{109}$ Corte IDH: Derechos y garantías de niñas y niños en el contexto de la migración y/o en necesidad de protección internacional, párr. 220.

110 Comisión IDH: Caso de los 120 ciudadanos cubanos y 8 ciudadanos haitianos detenidos en Las Bahamas.

111 Cantor y Barichello (2014), p. 697.

112 San Juan y Manly (2004), p. 61.

113 Los instrumentos de la tradición latinoamericana contienen también una delimitación acerca de quiénes pueden beneficiarse del asilo. Así, por ejemplo, la Convención de Caracas sobre Asilo 
Esto incluye la Declaración Americana, las Declaraciones de Naciones Unidas y la Convención de 1951 y su Protocolo.

Las declaraciones de las Naciones Unidas mencionan a las personas perseguidas de modo genérico: el artículo 14 de la Declaración Universal de los Derechos Humanos comienza con la frase "en caso de persecución" y el artículo 1 de la Declaración sobre Asilo Territorial habla de las personas "que tengan justificación para invocar el artículo 14 de la Declaración Universal de los Derechos Humanos, incluidas las personas que luchan contra el colonialismo".

La Convención sobre el Estatuto de los Refugiados, finalmente, tiene una definición compleja. Se entiende por refugiado a la persona que "como resultado de acontecimientos ocurridos antes del 1 de enero de 1951 y debido a fundados temores de ser perseguida por motivos de raza, religión, nacionalidad, pertenencia a determinado grupo social u opiniones políticas, se encuentre fuera del país de su nacionalidad y no pueda o, a causa de dichos temores, no quiera acogerse a la protección de tal país; o que, careciendo de nacionalidad y hallándose, a consecuencia de tales acontecimientos, fuera del país donde antes tuviera su residencia habitual, no pueda o, a causa de dichos temores, no quiera regresar a él" (artículo 1.A.2). Según el texto original de la Convención, los Estados podían decidir, al momento de la firma, ratificación o adhesión, limitar el alcance de la misma a los acontecimientos producidos en Europa (artículo 1.B.1). El Protocolo posterior estableció que esta definición debía leerse sin las limitaciones temporal y espacial (artículo I.2).

La definición de la Convención de 1951 ha sido recogida por la jurisprudencia de la Corte Interamericana, aclarando que el término refugiado "es aplicable también a aquellas personas que han huido de sus países de origen porque su vida, seguridad o libertad han sido amenazadas por la violencia generalizada, la agresión extranjera, los conflictos internos, la violación masiva de los derechos humanos u otras circunstancias que hayan perturbado gravemente

Territorial señala primeramente que todo Estado puede admitir en su territorio a las personas que juzgue conveniente admitir, por lo que daría a la figura del asilo una dimensión realmente muy amplia. Sin embargo, luego es más precisa al hablar de personas que "sean perseguidas por sus creencias, opiniones o filiación política o por actos que puedan ser considerados como delitos políticos" (artículo II), o bien personas "perseguidas por motivos o delitos políticos" (artículo III) o incluso personas requeridas de extradición que "sean perseguidas por delitos políticos o por delitos comunes cometidos con fines políticos" o "cuando la extradición se solicita obedeciendo a móviles predominantemente políticos" (artículo IV). En cualquier caso, hay que recordar que las personas mencionadas por esta Convención como susceptibles de recibir asilo no tienen un derecho a buscar y recibir asilo, que de ningún modo es reconocido por la Convención. La enumeración se refiere a las personas a las que un Estado puede otorgar asilo, no a las personas que pueden reivindicar un derecho de asilo. 
el orden público"114. Este último agregado, como se puede apreciar, recoge el contenido de la Declaración de Cartagena. La definición de Cartagena amplía el espectro del término refugiado constituyendo, respecto de la definición de la Convención, una definición ampliada ${ }^{115}$.

Sobre esta base, la Corte realizó una síntesis de los requisitos que, de acuerdo con la Convención de 1951 y su Protocolo de 1967, son necesarios para el reconocimiento de la condición de refugiado. Ellos son: 1) estar fuera del país de origen, esto es el país de nacionalidad o, en caso de las personas apátridas, de residencia habitual; 2) tener un temor fundado; 3) de persecución o amenaza de persecución; 4) que el motivo de ésta haya sido la raza, religión, nacionalidad, pertenencia a determinado grupo social u opiniones políticas, y 5) que no se pueda o, a causa de temores, no se quiera acoger a la protección interna del país de origen ${ }^{116}$. La definición de refugiado es integral, lo cual significa que se debe cumplir con todos y cada uno de los elementos mencionados para obtener el reconocimiento ${ }^{117}$.

Los niños son también titulares del derecho a buscar y recibir asilo ${ }^{118}$. Respecto de ellos, además de las causas tradicionales de persecución, han de tenerse en cuenta situaciones particulares que puedan afectarlos como tales como el reclutamiento, la trata, la mutilación genital femenina, el crimen organizado y la violencia ejercida por grupos no estatales ${ }^{119}$.

Una vez determinada la condición de asilado de una persona, "ésta la conserva a no ser que quede comprendida en el supuesto de una de las cláusulas de cesación"120. Dichas cláusulas se encuentran contenidas en los párrafos 1) a 6) de la sección C del artículo 1 de la Convención de 1951. Estas circunstancias son acogerse nuevamente a la protección del país de su nacionalidad, recuperar la nacionalidad perdida anteriormente, adquirir una nueva nacionalidad y acogerse a la protección de ese país, restablecerse en el país donde se había sufrido persecución, y la desaparición de las circunstancias que

${ }^{114}$ Corte IDH: Derechos y garantías de niñas y niños en el contexto de la migración y/o en necesidad de protección internacional, párr. 49.

115 Galindo (2002b), p. 56.

116 Corte IDH: Derechos y garantías de niñas y niños en el contexto de la migración y/o en necesidad de protección internacional, párr. 75.

117 Corte IDH: Derechos y garantías de niñas y niños en el contexto de la migración y/o en necesidad de protección internacional, párr. 75.

118 Corte IDH: Derechos y garantías de niñas y niños en el contexto de la migración y/o en necesidad de protección internacional, párr. 80.

${ }^{119}$ Corte IDH: Derechos y garantías de niñas y niños en el contexto de la migración y/o en necesidad de protección internacional, párr. 80.

${ }^{120}$ Corte IDH: Familia Pacheco Tineo, párr. 148. 
permitían definirla como refugiada que le permiten acogerse a la protección del país de su nacionalidad o, en caso de ser apátrida, regresar al país de su residencia ${ }^{121}$. Estas causales deben interpretarse restrictivamente ${ }^{122}$.

Finalmente, hay que tener en cuenta que las disposiciones de la Convención no son aplicables a quienes gocen de otra protección de Naciones Unidas, a quienes gocen de los derechos que un determinado Estado reconoce a sus nacionales y a los autores de determinados delitos graves (artículos 1.D, 1.E y 1.F) ${ }^{123}$. Éstas son las denominadas causales de exclusión de la protección de la Convención de 1951. Según la Comisión Interamericana, ha de entenderse que estas causales complementan la disposición de la Declaración Americana (y de

\footnotetext{
121 "En los casos que se enumeran a continuación, esta Convención cesará de ser aplicable a toda persona comprendida en las disposiciones de la sección A precedente: 1) Si se ha acogido de nuevo, voluntariamente, a la protección del país de su nacionalidad; o 2) Si, habiendo perdido su nacionalidad, la ha recobrado voluntariamente; o 3) Si ha adquirido una nueva nacionalidad y disfruta de la protección del país de su nueva nacionalidad; o 4) Si voluntariamente se ha establecido de nuevo en el país que había abandonado o fuera del cual había permanecido por temor de ser perseguida; o 5) Si, por haber desaparecido las circunstancias en virtud de las cuales fue reconocida como refugiada, no puede continuar negándose a acogerse a la protección del país de su nacionalidad. Queda entendido, sin embargo, que las disposiciones del presente párrafo no se aplicarán a los refugiados comprendidos en el párrafo 1 de la sección A del presente artículo que puedan invocar, para negarse a acogerse a la protección del país de su nacionalidad, razones imperiosas derivadas de persecuciones anteriores. 6) Si se trata de una persona que no tiene nacionalidad y, por haber desaparecido las circunstancias en virtud de las cuales fue reconocida como refugiada, está en condiciones de regresar al país donde antes tenía su residencia habitual. Queda entendido, sin embargo, que las disposiciones del presente párrafo no se aplicarán a los refugiados comprendidos en el párrafo 1 de la sección A del presente artículo que puedan invocar, para negarse a acogerse a la protección del país donde tenían residencia habitual, razones imperiosas derivadas de persecuciones anteriores".

122 Corte IDH: Pacheco Tineo, párr. 149.

123 “D. Esta Convención no será aplicable a las personas que reciban actualmente protección o asistencia de un órgano u organismo de las Naciones Unidas distinto del Alto Comisionado de las Naciones Unidas para los Refugiados. Cuando esta protección o asistencia haya cesado por cualquier motivo, sin que la suerte de tales personas se haya solucionado definitivamente con arreglo a las resoluciones aprobadas sobre el particular por la Asamblea General de las Naciones Unidas, esas personas tendrán ipso facto derecho a los beneficios del régimen de esta Convención".

"E. Esta Convención no será aplicable a las personas a quienes las autoridades competentes del país donde hayan fijado su residencia reconozcan los derechos y obligaciones inherentes a la posesión de la nacionalidad de tal país".

"F. Las disposiciones de esta Convención no serán aplicables a persona alguna respecto de la cual existan motivos fundados para considerar: a) Que ha cometido un delito contra la paz, un delito de guerra o un delito contra la humanidad, de los definidos en los instrumentos internacionales elaborados para adoptar disposiciones respecto de tales delitos; b) Que ha cometido un grave delito común, fuera del país de refugio, antes de ser admitida en él como refugiada; c) Que se ha hecho culpable de actos contrarios a las finalidades y a los principios de las Naciones Unidas".
} 
la Convención Americana, agregamos nosotros) sobre asilo ${ }^{124}$. La interpretación de estas cláusulas ha de ser restrictiva ${ }^{125}$, aunque respecto de las personas que están excluidas de la protección internacional por ser autores de determinados delitos, no es necesario que exista una condena penal previa, bastando la existencia de motivos fundados para considerar que se ha cometido tal delito ${ }^{126}$.

Una cuestión fundamental es la relativa a quién es competente para verificar la existencia de una causal que justifica el otorgamiento de asilo. Tratándose de la protección de una persona que se encuentra dentro del territorio del Estado parece natural que sea el propio Estado asilante el que califique la naturaleza de las circunstancias de las que huye el (supuesto) perseguido. Ésta parece ser la solución de la tradición latinoamericana en relación con el asilo territorial ${ }^{127}$. A pesar de las importantes diferencias ya señaladas entre la figura del asilo en la tradición latinoamericana (donde se configura como un acto de discrecionalidad estatal) y en los sistemas de Derechos Humanos (donde se configura como un derecho del individuo), el mismo criterio puede aplicarse en relación con estos últimos. Sin embargo, en el contexto de los sistemas de Derechos Humanos, la determinación que haga el Estado estará sujeta a escrutinio, dentro de los límites señalados en los apartados anteriores de este trabajo, por las instancias internacionales encargadas de velar por la efectividad de los instrumentos respectivos. En la tradición latinoamericana, en cambio, la determinación sobre la existencia de una causal de asilo puede ser objeto de controversia entre el Estado asilante y el Estado que persigue al asilado (normalmente, el de la nacionalidad de este último).

${ }^{124}$ Comisión IDH: Informe sobre la situación de los derechos humanos de los solicitantes de asilo en el marco del sistema canadiense de determinación de la condición de refugiado, párr. 58.

${ }^{125}$ Comisión IDH: Informe sobre la situación de los derechos humanos de los solicitantes de asilo en el marco del sistema canadiense de determinación de la condición de refugiado, párr. 58.

${ }^{126}$ Comisión IDH: Informe sobre la situación de los derechos humanos de los solicitantes de asilo en el marco del sistema canadiense de determinación de la condición de refugiado, párr. 59.

127 Galindo (2002a), p. 42. Esta conclusión se ve reforzada por el artículo XI de la Convención de Caracas sobre asilo territorial que establece que en casos de reclamaciones o requerimientos de un Estado a otro, "la apreciación de la prueba presentada por el Estado requirente dependerá del criterio del Estado requerido". Es verdad, sin embargo, que este artículo no parece autorizar una calificación puramente discrecional por parte del Estado asilante, sino que se refiere a que este último tiene cierta libertad para apreciar las pruebas que presente el Estado requirente. Por ello parece que la interpretación correcta sería que si el Estado requirente no presenta prueba alguna, el Estado requerido goza de un margen importante de discrecionalidad. Pero si el requirente presenta pruebas, la discrecionalidad del requerido se ve limitada a la apreciación de esas pruebas. Como ya es sabido, la Convención de Caracas se ubica en una lógica de relaciones interestatales. Por ello, las garantías que allí están mencionadas tienden a asegurar la posición de los Estados intervinientes, pero no los derechos del (supuesto) perseguido. 
Finalmente, hay que tener en cuenta que el reconocimiento de la condición de asilado puede tener consecuencias para terceros Estados, ya que según la Corte Interamericana, "una vez declarado por un Estado, el estatuto de refugiado protege a la persona a la cual le ha sido reconocido más allá de las fronteras de ese Estado, de modo que otros Estados en los que ingrese esa persona deben tomar en cuenta tal condición al momento de adoptar cualquier medida de carácter migratorio a su respecto y, por ende, garantizar un deber de precaución especial en la verificación de tal condición y en las medidas que pueda

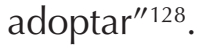

\section{Conclusiones}

Hemos comenzado este trabajo intentando una delimitación del concepto de asilo a través de su comprensión histórica. Hemos señalado la existencia de tres sistemas que, en el ámbito americano, tienen incidencia sobre el tema: la denominada tradición latinoamericana, el sistema interamericano de Derechos Humanos y el sistema universal de Derechos Humanos. En cada uno de estos sistemas se utilizan varias expresiones (asilo, refugio y otras derivadas de éstas) para hacer referencia a mecanismos de protección internacional que, aunque tienen diferencias entre sí, son sustancialmente semejantes.

Sin embargo, estos mecanismos no operan aisladamente. En este trabajo hemos mostrado los vínculos de la institución del asilo en el sistema interamericano con los demás sistemas. En este sentido, debe recordarse que tanto la Convención como la Declaración Americanas reconocen el derecho a buscar y recibir asilo de acuerdo con la legislación nacional y los convenios internacionales. Si bien en un primer momento el reenvío a los convenios internacionales podría entenderse relativo a los instrumentos de la tradición latinoamericana de asilo (al aprobarse la Declaración Americana ninguno de los instrumentos del sistema universal existían todavía), la preferencia actual de la Corte Interamericana es la de considerar el reenvío a los instrumentos del sistema universal.

La consecuencia fundamental de esta forma de considerar el reenvío es que puede entenderse entonces que los instrumentos interamericanos de Derechos Humanos reconocen un verdadero derecho a recibir asilo. En efecto, los tratados de la tradición latinoamericana se referían al asilo como una prerrogativa que relevaba de la pura discrecionalidad estatal, mientras que en el contexto de la Convención de 1951 sobre el Estatuto de los Refugiados puede argumentarse (aunque no sea opinión unánime) que recibir asilo es un verdadero derecho.

${ }^{128}$ Corte IDH: Familia Pacheco Tineo, párr. 150. 
Sin embargo, la Corte Interamericana, aunque reconoce que existe un verdadero derecho a recibir asilo, admite que los Estados tienen cierto margen de discrecionalidad a la hora de considerar las circunstancias concretas que permiten tal reconocimiento. Así, aunque la Corte ha reconocido que tiene competencia para verificar si se han cumplido las garantías del debido proceso en la determinación del estatuto de refugiado, no está dispuesta a hacer una reevaluación sobre el mérito de la decisión estatal.

\section{BiBLIOGRAFÍA CITADA}

Arlettaz, Fernando (2013): "Extranjeros, migrantes y trabajadores migrantes en la jurisprudencia interamericana", en: Revista de derecho migratorio y extranjería (№ 36), pp. 247-260.

(2015): Expulsión de extranjeros y derecho de asilo en el sistema interamericano (Centro Nacional de Derechos Humanos, México).

Buriano Castro, Ana; Dutrenit Bielous, Silvia y Rodríguez de Ita, Guadalupe (2008): "Protección internacional y derechos de los perseguidos políticos en la experiencia mexicana", en: Papeles de Población ( $\left.N^{\circ} 57\right)$, pp. 93-116.

CançAdo Trindade, Antônio (1996): "Derecho Internacional de los Derechos Humanos, Derecho Internacional de los Refugiados y Derecho Internacional Humanitario: aproximaciones y convergencias", en: Thomas BuERGENTHAL y Antônio Cançado Trindade, Estudios Especializados de Derechos Humanos I (San José, IIDH).

Cantor, David James; Barichello, Stefania Eugenia (2014): "Protection of Asylum-Seekers Under the Inter-American Human Rights System", en: Ademola AbAss y Francesca IPPOLITO, Regional Approaches to the Protection of Asylum Seekers: an International Legal Perspective (Ashgate, Farnham), pp. 267-294.

Cantor, David James; Barichello, Stefania Eugenia (2013): "The Inter-American human Rights system: a new model for integrating refugee and complementary protection?", en: The International Journal of Human Rights ( $\mathrm{N}^{\circ} 17$, 5-6), pp. 689-706.

Díez de Velasco, Manuel (1985): Instituciones de Derecho Internacional Público (Madrid, Tecnos).

ESPONDA FERNÁNDEZ, Jaime (2004): "La tradición latinoamericana de asilo y la protección internacional de los refugiados", en: Leonardo Franco, El asilo y la protección internacional de los refugiados en América Latina (San José, IIDH-Universidad Nacional de Lanús-ACNUR), pp. 79-125. 
Fischel de AndRade, José H. (2001): "Derecho de los refugiados en América Latina: reflexiones sobre su futuro", en: Sandra NamiHAS, Derecho internacional de los refugiados (Lima, Pontificia Universidad Católica del Perú), pp. 95-107.

Galindo Vélez, Francisco (2002a): "El asilo en el sistema de las Naciones Unidas y en el sistema interamericano", en: AA.VV., Compilación de instrumentos jurídicos regionales relativos a derechos humanos, refugio y asilo (México, ACNUR).

(2002b): "Consideraciones sobre la determinación de la condición de refugiado", en: Sandra Naminas, Derecho Internacional de los refugiados (Lima, Pontificia Universidad Católica del Perú), pp. 46-81.

Goodwin GiLl, Guy S. (1978): International Law and the Movement of Persons between States (Oxford, Clarendon Press).

Gros EsPielL, Héctor (1978): "La protección y asistencia internacional de los refugiados: posibilidades de cooperación al respecto entre el sistema de las Naciones Unidas y los regímenes regionales de protección de los derechos humanos, en especial América Latina", en: Round table on Some Current Problems of Refugee Law (Ginebra, UNHCR).

(1992): "El derecho internacional americano sobre asilo territorial y extradición en sus relaciones con la Convención de 1951 y el Protocolo de 1967 sobre el estatuto de los refugiados", en: Compilación de instrumentos jurídico interamericanos relativos al asilo diplomático, asilo territorial, extradición y temas conexos (ACNUR, San José).

(1995): "La Declaración de Cartagena como fuente del Derecho Internacional de los Refugiados en América Latina", en: ACNUR-IIDH, Memorias del coloquio 10 años de la Declaración de Cartagena sobre Refugiados (Coloquio de San José de Costa Rica, 1994) (San José, ACNUR-IIDH).

Kneebone, Susan (2009): "Introduction: Refugees and Asylum Seekers in the International Context-Rights and Realities", en: Susan KneEbone, Refugees, Asylum Seekers and the Rule of Law (Cambridge, Cambridge University Press), pp. 1-31.

Lauterpacht, Elihu y Bethlehem, Daniel (2003): The scope and content of the principle of non-refoulement (Informe para UNHCR).

O'Donnell, Daniel (2012): Derecho Internacional de los Derechos Humanos: normativa, jurisprudencia y doctrina de los sistemas universal e interamericano, $2^{a}$ edición (México, Superior Tribunal de Justicia del Distrito Federal).

Piza Escalante, Rodolfo y Cisneros Sánchez, Máximo (1982): "Algunas ideas sobre la incorporación del Derecho de Asilo y de Refugio al Sistema Interamericano de Derechos Humanos", en: AA.VV., Asilo y Protección Internacional de 
refugiados en América Latina (México, Universidad Autónoma de México), pp. 103-111.

Ruiz de SAntiago, Jaime (1991): "Consideraciones generales acerca del derecho internacional de los refugiados", en: CICR-IIDH-ACNUR-Consejo Andino para las Relaciones Internacionales, Jornadas sobre los sistemas internacionales de protección jurídica de la persona humana (Buenos Aires), pp. 24-101.

San Juan, César y Manly, Mark (2004) "El asilo y la protección internacional de los refugiados en América Latina: Análisis crítico del dualismo 'asilorefugio' a la luz del Derecho Internacional de los Derechos Humanos", en: Leonardo FrANCO, El asilo y la protección internacional de los refugiados en América Latina (San José, IIDH-Universidad Nacional de Lanús-ACNUR), pp. 31-75.

Sandoval, Clara (2005): "A Critical View of the Protection of Refugees and IDPs by the Inter-American System of Humans Rights: Re-assessing its Powers and Examining the Challenges for the Future", en: International Journal of Refugee Law (№ 17, 1), pp. 43-66.

\section{JURISPRUDENCIA CITADA}

Corte Internacional de Justicia (CIJ): Asylum case (Colombia v. Perú), sentencia de 20 de noviembre de 1950.

CIJ: Haya de la Torre case (Colombia v. Perú), sentencia de 13 de junio de 1951.

Corte Interamericana de Derechos Humanos (Corte IDH): Otros tratados: objeto de la función consultiva de la Corte, Opinión Consultiva OC 1/82 de 24 de septiembre de 1982, Serie A No 1, párr. 41.

Corte IDH: Condición jurídica y derechos de los migrantes indocumentados, Opinión Consultiva OC-18/03 de 17 de septiembre de 2003, Serie A No 18, voto concurrente del juez Cançado Trindade, párr. 38.

Corte IDH: Derechos y garantías de niñas y niños en el contexto de la migración y/o en necesidad de protección internacional, Opinión Consultiva OC-21/14 de 19 de agosto de 2014, Serie A No 21.

Corte IDH: Familia Pacheco Tineo vs. Bolivia, Sentencia de 25 de noviembre de 2013, Serie C No 272.

Comisión IDH: Informe sobre la situación de los Derechos Humanos en Argentina, 11 de abril de 1980.

Comisión IDH: Comité Haitiano de Derechos Humanos y otros (Estados Unidos), Informe 51/96 de 13 de marzo de 1997, caso 10.675. 
Comisión IDH: Abella (Argentina), Informe No 55/97 de 18 de noviembre de 1997, caso 11.137.

Comisión IDH: Informe sobre la situación de los derechos humanos de los solicitantes de asilo en el marco del sistema canadiense de determinación de la condición de refugiado, 28 de febrero de 2000.

Comisión IDH: Informe sobre terrorismo y derechos humanos, 22 de octubre de 2002.

Comisión IDH: Andrea Mortlock (Estados Unidos), Informe de admisibilidad y fondo $\mathrm{N}^{\circ}$ 63/08 de 25 de julio de 2008, caso 12.534 .

Comisión IDH: John Doe y otros (Estados Unidos), Informe de fondo No 78/11 de 21 de julio de 2011, caso 12.586 .

Comisión IDH: Derechos humanos de los migrantes y otras personas en el contexto de la movilidad humana en México, 30 de diciembre de 2013.

\section{OtROS DOCUMENTOS}

ACNUR (Alto Comisionado de las Naciones Unidas para los Refugiados, 1992): Handbook on Procedures and Criteria for Determining Refugee Status (Ginebra, ACNUR), pp. 4-5.

ACNUR (Alto Comisionado de las Naciones Unidas para los Refugiados, 2013): "Presentación oral del ACNUR ante la Corte Interamericana de Derechos Humanos dentro del marco de solicitud de Opinión consultiva sobre niños migrantes, presentada por MERCOSUR", disponible en: http://www.refworld. org/cgi-bin/texis/vtx/rwmain/opendocpdf.pdf?reldoc=y\&docid=52a5b0804, 2013 [visitado el 30 de enero de 2015].

Asamblea General de la OEA: Situación jurídica de los asilados, refugiados y personas desplazadas en el continente americano, Resolución AG/RES. 774(XV-O/85), aprobada en la tercera sesión plenaria, celebrada el 9 de diciembre de 1985.

Conclusiones y recomendaciones del coloquio sobre el asilo y la protección internacional de refugiados en América Latina (Tlatelolco, Ciudad de México), 11 al 15 de mayo de 1981.

Declaración de Tlatelolco sobre acciones prácticas en el derecho de los refugiados en América Latina y el Caribe, 1999, adoptada por los participantes en el Seminario Regional sobre Acciones Prácticas en el Derecho de los Refugiados, Ciudad de México, 10 y 11 de mayo de 1999.

Institut de Droit International: Reunión de Bath de 11 de septiembre de 1950, Annuaire, 1950. 